\title{
A New Hope for Europhiles? The 2017 German Federal Elections and the Revenge of the Pro-European Mainstream
}

\author{
Stuart J. Turnbull-Dugarte
}

s.turnbull-dugarte@soton.ac.uk

***Paper accepted for publication in the Journal of European Integration***

The rise of the right-wing populist and eurosceptic party, Alternative für Deutschland, in Germany represents a significant shake up of the country's pro-EU consensus. Spatial models of partisan behaviour predict that mainstream parties are likely to react to eurosceptic challenges by veering towards a more critical european position. A comparison of the politicisation of European integration in party programmes between the 2017 federal elections and those held previously shows that the reverse is true. In the face of a rising eurosceptic challenger, mainstream parties became more pro-European and more explicitly vocal in their support for the EU as the AfD expanded its support in advance of the 2017 election. In short, instead of accommodating to euroscepticism, mainstream parties have opted for an adversarial response. I argue that the europhile fightback of mainstream parties is likely driven by increases in europhilia amongst mainstream parties' supporters in the face of the AfD.

Keywords: politicisation; European integration; mainstream parties, challenger parties, Germany, Alternative für Deutschland 


\section{Introduction}

The electoral triumph of the eurosceptic Alternative für Deutschland (AfD) party in the 2017 German federal elections represents a significant watershed moment in the country's post-war history. After failing to garner enough votes to obtain parliamentary representation during its first electoral competition in the 2013 federal election, the AfD became the third largest party in Germany after the 2017 election taking home $11.5 \%(12.6 \%)$ of the constituency (list) vote share and occupying ninety-four seats in the German Bundestag. Not only is the AfD the first populist radical right-wing party in Germany to gain national-level parliamentary representation since the 1960s (Berbuir et al., 2015) but it is also the first to do so whilst openly questioning the country's membership of the European Union's (EU) common currency.

The rise of challenger parties challengers across Western Europe has reshaped party systems, which have previously been resilient to entrepreneurial success (De Vries and Hobolt, 2020), and this has consequences for the behaviour of other parties within the system. How has the electoral success of a eurosceptic challenger affected the politicisation of EU integration amongst the established mainstream parties in Germany? Political parties are believed to respond to electoral threats (Downs 1957). The emergence and persistent electoral successes of the AfD in Germany represents such a threat and, as a result, one might expect political parties operating within the mainstream to react by closing the spatial gap between their own political offering on Europe and that of the entrepreneur. I deliver an empirical test of this argument by analysing changes in the politicisation of the EU in the 2017 federal elections. I find 
strong evidence that mainstream parties across both the left and right in Germany are not assimilating their positions on EU integration to cater to the emergence of the eurosceptic competitor. In fact, party positions in 2017 became substantively more europhile than in recent elections. In other words, the German mainstream are not only resisting spatial incentives to become more eurosceptic, they are actually striking back against the eurosceptic offering afforded by the AfD and providing a new avenue for electoral competition over EU integration with a vocally strong europhile voice. Moreover, analysing individual-level survey data, I show that increased support for European integration amongst supporters of the main coalition parties might explain the adversarial pro-European shift by parties who view EU integration as a strategic policy with high issue yield (DeSio and Weber, 2014).

The paper provides evidence that challenges predominant assumptions regarding the responsiveness of parties to emerging challengers that disrupt the spatial arena of political competition (Abou-Chadi and Krause, 2018) and specifically in relation to European integration (Meijers, 2017; Williams and Ishiyama, 2018). The results of the case at hand suggest that entrepreneurial euroscepticism is not necessarily contagious, but rather can also lead to some parties adopting an adversarial (Meguid, 2005) response and doubling down on their pro-European identity. 


\section{Theoretical expectations}

Adaptations in the policy positions of political parties have largely been presented to be the result of spatial incentives of party competition as theorised by Downs (1957). In the spatial model, parties are understood to be largely driven by vote-maximising incentives. As a result, parties are viewed as amenable vessels that will modify their policy positions, within the boundaries of their ideological confines (Budge et al., 2010; Walgrave and Nuytemans, 2009), to become closer to the median voter in the electorate (Adams et al., 2014; Schumacher et al., 2013). Voters are assumed to be rational decision-makers who seek to vote for parties that promote policy positions that align most closely with their own political preferences. The main assumption, therefore, of the spatial model is that parties react to shifts in electoral preferences ${ }^{i}$ and is also identified as the driver of changes in the politicisation of the $\mathrm{EU}$ and levels of europscepticism in party positions (Arnold et al., 2012; Spoon and Williams, 2017; Steenbergen et al., 2007; Williams and Spoon, 2015) as well as the primary explement of the traditional lack of electoral salience given to the $\mathrm{EU}$ in the pre-crisis period (Mair, 2000).

The spatial rationale, however, has been applied to explain how shifts in party positions can often materialise as the result of changes in the behaviour of political competitors with the wider party system or when partisan entrepreneurs emerge. In this framework parties are understood to react responsively to electoral threats caused by new parties that trigger shifts in the competitive partisan marketplace with existing 
parties spatially adjusting their own policy positions to be closer to that of the challenger. Doing so allows the existing parties to ensure that emerging competitors are not able to monopolise the spatial position they create and, in response, mainstream parties seek to "fill the gap" and "take the wind out of [their competitors'] sails" (Downs 1957, 131).

Downs' model, however, assumes a two-party and unidimensional political space which is often not reflected in the real-world dynamics of competition in European states (Bakker et al., 2012). A large body of literature has emerged since Downs that assesses the impact of emerging challenger parties within the multiparty and multidimensional European space, which confirm the expectations of the competitor-oriented spatial model. Parties across a host of multiparty European democracies are found to adapt to positional shifts brought about by changes in their competitors' policy supply within the political market (Adams and Somer-Topcu, 2009). The rise of populist and radical right-wing challenger parties has been linked to mainstream parties shifting their positions and issue emphasis to become closer to that of the challenger (Bale, 2003; Han, 2015; Schumacher and van Kersbergen, 2014) including specifically on GAL-TAN ${ }^{\mathrm{ii}}$ issues like immigration (Abou-Chadi and Krause, 2018; Bale et al., 2010; Carvalho, 2013; Van Spanje, 2010). The effect of competitor-based contagion is not unique to parties operating on the right, however, with the introduction and electoral success of Green parties leading to the co-opting of pro-environmental measures by parties on the centre-left (Abou-Chadi, 2016). The shifts in parties positions tends to be greatest 
amongst those parties that belong to a similar ideological family with right-wing parties responding more to threats on their right and left-wing parties adapting to parties further on their left (Adams and Somer-Topcu, 2009).

Spatial-based explanations of parties responding to the behaviour of their political competitors can also be applied beyond the traditional bidimensional space of liberal/left vs. conservative/right and explain policy adaptations related to EU integration. Generally, the literature establishes a strong link between the rise of eurosceptic challengers and the shifting position of mainstream parties towards such positions (Conti, 2018; Meijers, 2017; Somer-Topcu, 2009; Williams and Ishiyama, 2018). Distinctively from party shifts across the left-right (labour-capital) axis caused by emerging challengers, Meijers (2017) argues that the risk of contagious euroscepticism is not limited to the challengers from the same ideological family, with centre-left parties actually being more likely to co-opt eurosceptic messages from challengers given that their voting constituents are haemorrhaged by eurosceptic messaging on both the far-left and far-right. Shifts towards euroscepticism engendered by emerging challengers are not then conditional on having ideological parity with the pretender.

Importantly, filling the spatial gap and accommodating challengers' policies is not the only strategy available to mainstream parties. Alternatives include adversarial approaches (Meguid, 2005) with parties increasing their spatial divergence between the 
challenger, a hold response (Bale et al., 2010) with parties consciously not responding, or the defuse strategy whereby parties seek to decrease the saliency of the issue 'owned' by the challenger by increasing the saliency of another issue (Bale et al., 2010; Meguid, 2005). Whilst existing empirical work on the issue of EU integration argues that parties tend to respond to eurosceptic threats by acting to accommodate euroscepticism (Meijers, 2017), in the case of Germany the evidence presented here points towards an alternative adversarial response.

The German party system provides us with an ideal case for testing the impact of an emerging eurosceptic challenger on the politicisation of EU integration among mainstream parties. Germany is the EU's most powerful and populated state in the EU. Its population has historically enjoyed pro-European consensus and its party system has, until now, been free of any electorally successful eurosceptic party. In terms of gaining parliamentary representation, the AfD is Western Europe's most successful eurosceptic party so if euroscepticism is indeed contagious, we would expect to see its effects at play in the country where a eurosceptic party has enjoyed such success.

\subsection{Germany, euroscepticism and the rise of the AfD}

Since the beginning of the financial crisis there has been a rapid shift in the levels of public support for the supranational polity with there being a notable rise in public euroscepticism and an increase in the saliency of the EU (Rohrschneider and 
Whitefield, 2017) echoing general increases in the politicisation of the EU within the public sphere across a wide pool of EU member states (Hutter and Grande, 2014). Data from the Eurobarometer shows that the percentage of the German population who hold a positive image ${ }^{\mathrm{iii}}$ of the EU has remained below 50\% (Figure 1) and observed a marked slump between 2009 and 2017.

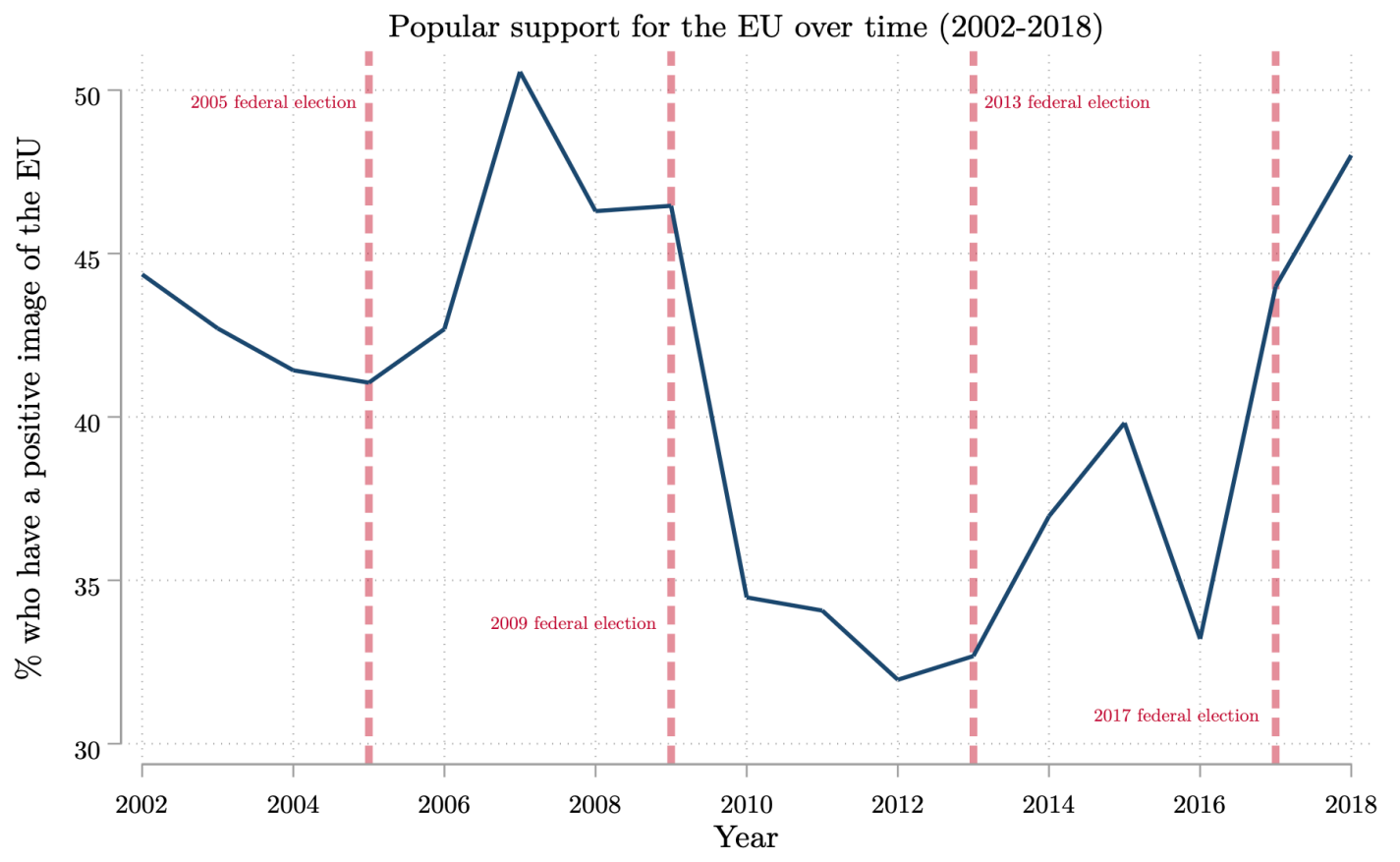

Figure 1: Popular attitudes towards the EU

This was exacerbated during the subsequent Eurozone crisis, which represented an intense period of European integration (Devine, 2019), that became domestically salient in 2010 (Schneider and Slantchev, 2018), followed by the 2015 refugee crisis ${ }^{\text {iv }}$ that drew widespread criticism against both the Merkel administration and the EU (Mader and Schoen, 2019; Marx and Naumann, 2018). Despite this shift in public opinion in 
relation to the EU, little empirical evidence suggests that there has been a transformation in the levels of euroscepticism amongst mainstream political parties in Germany (although, see Rohrschneider and Whitefield (2017)).

The arrival of the AfD in the lead up to the 2013 election brought Germany's partisan pro-EU consensus to an end ${ }^{\mathrm{v}}$ with the AfD campaigning on an aggressively eurosceptic platform structured around apposition to the country's membership of the common currency (Arzheimer, 2015; Berbuir et al., 2015). The party won $4.7 \%$ of the vote, only just failing to reach the $5 \%$ threshold required to gain representation in the Bundestag. Despite this initial electoral setback, however, the eurosceptic challenger has consolidated its position within the party system in the aftermath of 2013 . The party performed well in the 2014 European Parliament (EP) elections where it took home $7.1 \%$ of the national vote and acquired seven seats in the EP. The success observed in the EP elections, which can serve as a springboard for challenger parties (SchulteCloos, 2018), was echoed in a number of state-level elections held throughout 2015 and 2016 with the party earning parliamentary representation in fourteen of the sixteen German Länder [states] before the 2017 federal election took place (Schmitt-Beck, 2017)

By 2017 the AfD could no longer be considered an insignificant threat and represented a viable eurosceptic alternative for voters. Despite offering a clear anti-European policy offering in the 2013 election, the AfD, as an electoral virgin, was unlikely viewed as a 
viable option for many voters given the high electoral threshold for representation in the Bundestag (5\%) and the fact that no radical right-wing party had achieved representation at the national level since the 1960s (Berbuir et al., 2015). The same cannot be said for the 2017 federal elections where the party was able to appeal to voters after banking a number of significant electoral triumphs in successive elections at both the supranational and subnational level. The contagiousness of europscepticism is found to be driven by the electoral successes of the eurosceptic threat rather than by the existence of euroscepticism alone (Somer-Topcu, 2009). Given that the AfD gained consistently good results during the subnational and EP elections that took place between the 2013 and 2017 federal elections, the established parties should become more likely to increase the responsiveness of their European positions as the electoral threat of the challenger has clearly increased.

\section{Data and analysis}

In order to test this hypothesis, the analysis relies on coded manifesto data using the Manifesto Project (MARPOR). The selection of manifestos as the main source is commonplace within the party literature and remains one the most appropriate data source for assessing changes party positions (Budge, 2001) vi .

Observations represent the given manifesto for a party in each election $(\mathrm{N}=27)$ between the 2002 and 2017 federal elections. The main dependent variables are a party's overall position on EU integration and the saliency given to the issue of Europe 
within the party's manifesto in each election. MARPOR indicates positions based on the difference between positive and negative statements given to a specific policy dimension and measures saliency as the percentage of the manifesto document dedicated to the policy concern. As recommended by Lowe et al. (2011) I rely on logged values of position and saliency (details and summary statistics provided in the appendix).

\subsection{Comparing partisan politicisation of the EU in 2013 \& 2017}

Figure 2, plots parties' positions in EU integration in the two most-recent elections. Across the board there has been in an increase in the level of europhilia from all of the mainstream political parties in 2017. Of note is that the party most critical of the EU in 2013 (die Linke) became more pro-European in 2017 than the most pro-European party in 2013 (die Grünen). In fact, all of the parties in 2017 adopted a position on the EU closer to europhile than die Grünen did in 2013. Notably, the main right-wing party alliance between the CDU/CSU follows this trend in becoming more notably proEuropean. This is significant as it is at odds with theoretical expectations regarding the responsiveness of parties to eurosceptic challengers (Meijers, 2017) and amongst rightwing parties facing an electoral threat from political entrepreneurs emerging to their right (Abou-Chadi and Krause, 2018; Bale, 2003). Given that the AfD is ideologically closest (on the prominent left-right dimension) to the CDU/CSU, the CDU/CSU have the greatest electoral incentives to react to the threat represented by the AfD to their share of the electoral market. Whilst the party responded to the electoral gains of the 
AfD, their response has been adversarial (Meguid, 2005), doubling down on their proEuropean stance and becoming more actively europhile, marking their spatial distinctiveness on the European dimension from the AfD.

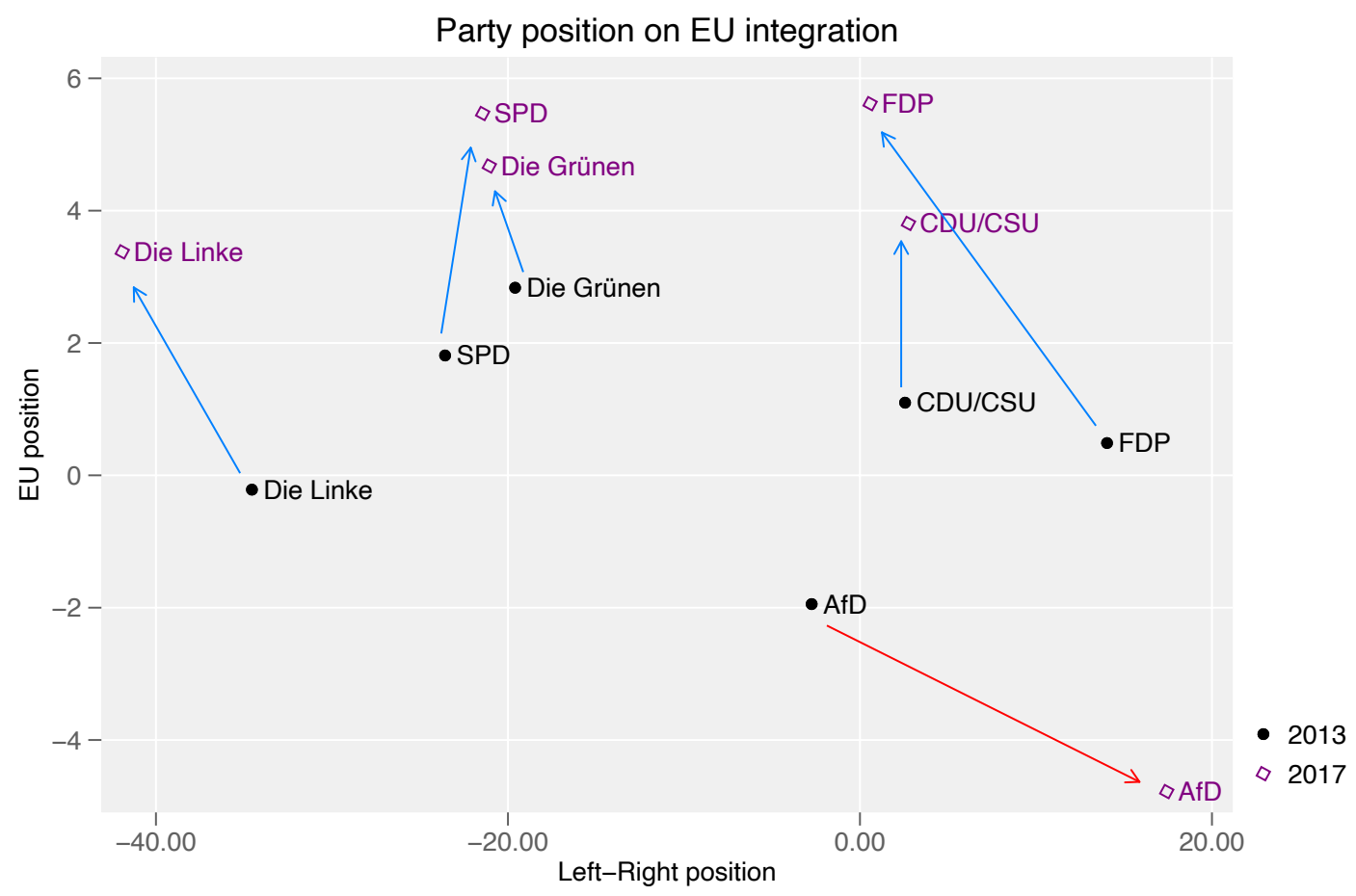

Figure 2: Party EU policy positions

Striking also, is the preferences to move away from euroscepticism observed by die Linke. As the only party that has leaned most closely towards a eurosceptic position (Hertner and Sloam, 2012; Lees, 2002) the party might have felt incentivised to reap the benefits of the politicisation of the EU caused by the AfD's messaging and by a change in electoral demands by consolidating their eurosceptic position as the original EU-critical option within the party system. Instead the party has moved considerably away from its own eurosceptic position in 2013, as well as that of the AfD. This may 
because the AfD's ownership of the eurosceptic message created a popular association between euroscepticism and the radical right that made die Linke's critical stance on the EU an unpalatable position for the party to maintain.

The AfD, too, has doubled down on its eurosceptic message, increasing the levels of euroscepticism in their 2017 electoral offering vis-à-vis 2013. The reader may note also, that whilst the CDU/CSU's position on the mainstream left-right dimension remained more or less constant, the AfD, in addition to experiencing a sizeable increase in euroscepticism in 2017, also moved further to the right both in comparison to its own position in 2013 as well as in comparison to its main political rival, which is consistent with popular assessments of the party's move rightwards (Giebler et al., 2019) as well as that of the party's main supporters (Arzheimer and Berning, 2019).

Figure 3 displays the level of partisan EU saliency in the 2013 and 2017 elections. On the whole, mainstream parties alter how much they are willing to speak about Europe in the same vein that they are willing to become more pro-European, with some exceptions. Of the three left-wing parties, only die Linke showed no change in the level of EU saliency between the two electoral contests. Therefore, whilst the party might become significantly more europhile in comparison to its traditional critical stance, it was not willing in 2017 to make concerns over Europe a (more) significant part of its platform. Conversely, both the SPD and die Grünen increased the importance of EUbased concerns in the programmes in the 2017 election. They, therefore, not only 
became more pro-European in 2017 but were also keen to give this stance more political weight in the most recent election, representing an adversarial strategy (Bale et al., 2010; Meguid, 2005). Although the CDU/CSU increased its support for the EU markedly between 2013 and 2017, it actually decreased the level of importance it gave to the issue in 2017. EU integration for the main right-wing party in 2017 was muted, in comparison to the previous election, which suggests that the party preferred to supress an issue that was likely to be more salient for its emerging rival. This is the strategic approach that Bale et al. (2010) pens as the "defuse" approach with parties responding to challenges by attempting to move saliency away from those issues owned by the challengers.

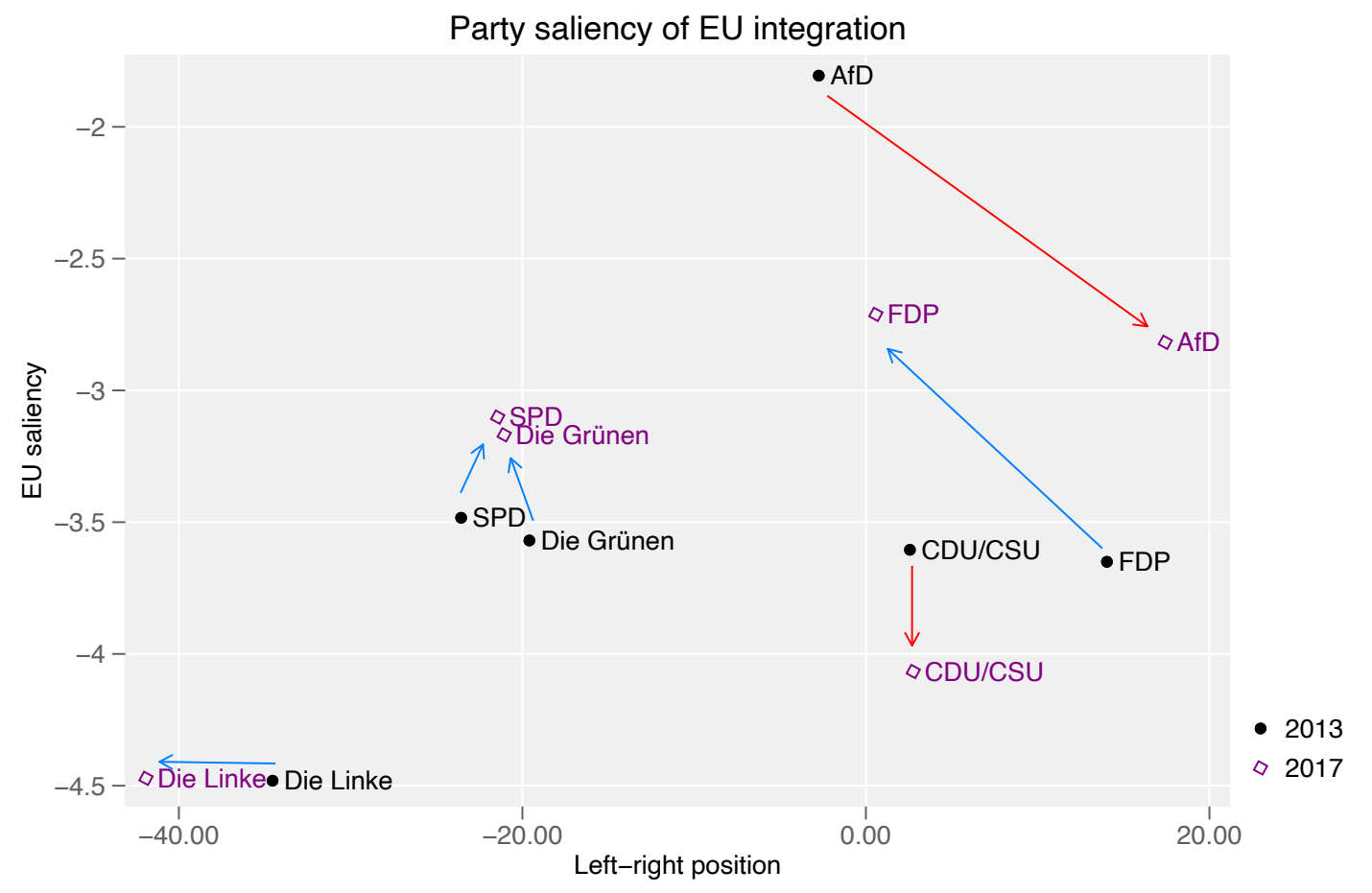

Figure 3: Party EU saliency 
The liberal party (FDP) did not behave in a similar fashion and, like the SPD and die Grünen, augmented the saliency of EU integration in the most recent elections. They too not only wished to mark their spatial distinction from the AfD on the European dimension but also sought to make this position more explicit to voters and dedicate more of their manifesto to talking about these issues.

The shifts in parties EU positions are significant. Table 1 reports the results of a t-test comparing partisan EU positions between elections. The table reports the output from a bivariate OLS regression with a single dichotomous indicator comparing the 2017 election to 2013 (columns 1 and 3) as well as those between 2002 and 2013 (columns 2 and 4). This simple test shows that the EU positions are, on average, significantly and substantively more europhile in 2017 in comparison to all elections that took place between 2002 and 2013. A visualisation of EU positions between 2002-2017 is included in the appendix (Figure A4). It shows the rise in europhilia in 2017 to be exceptional in comparison all previous elections When it comes to EU saliency, however, we do not see any change in the level of importance that mainstream parties are giving to the issue of Europe in 2017 compared to previous years. Testing for party-based asymmetry in the changes, does not reveal any heterogenous responsiveness despite there, theoretically, being a rationale for the right-leaning block to be more threatened by the AfD (Figure A1 in appendix). No party appears to have altered the saliency of the EU in their programmes. In other words, whilst parties are becoming more spatially 
distinct and adversarial (Meguid, 2005), parties are not, on average, increasing the relative salience of the issue "owned" by the challenger.

Table 1: T-test comparison of EU policy \& EU saliency

\begin{tabular}{lcc|cc}
\hline & \multicolumn{2}{c|}{ EU position } & \multicolumn{2}{c}{ EU saliency } \\
& 2017 vs 2013 & 2017 vs pre-2017 & 2017 vs 2013 & 2017 vs pre-2017 \\
\hline \multirow{4}{*}{ Difference } & $3.72^{* * *}$ & $3.24^{* * *}$ & 0.37 & 0.08 \\
& $(0.72)$ & $(0.55)$ & $(0.36)$ & $(0.24)$ \\
Observations & 11 & 26 & 11 & 26 \\
\hline
\end{tabular}

Standard errors in parentheses

*** $\mathrm{p}<0.01,{ }^{* *} \mathrm{p}<0.05,{ }^{*} \mathrm{p}<0.1$

Of course, one might argue that the 2017 election simply represents a general change in the ideological positions of parties and is not, therefore, symbolic of any EU-centric change in partisan positions driven by the rise of the AfD. This is, however, not the case. In addition to the main tests presented here, I test for changes in parties general ideological (left-right) position as well as their attitudes towards immigration - the twin issue of EU integration (Brinkmann and Panreck, 2019). There is no evidence that parties' europhile turn is taking place on the back of other position shifts (see Figure A2 and A3 in the appendix).

Altering their position to become more eurosceptic, doubling down on their support for the EU or changing the saliency of EU integration are, however, not the only strategic responses available to mainstream parties to defend against a eurosceptic challenger. Political parties competing in a multidimensional political arena can respond to 
electoral threats regarding polemical policy issues that do not incentivise them to take a clearly unambiguous policy position by blurring their stance on an issue (Bräuninger and Giger, 2018; Rovny, 2012; Turnbull-Dugarte, 2020b). This strategy has been employed by pro-EU parties in a number of member states, particularly by larger catch-all parties with voter constituencies divided in their support for the EU (Adam et al., 2017). Comparing the level of clarity given to the issue of EU integration between the 2017 and 2013 elections (detailed operationalisation in appendix), the results show that, on average, parties actually decreased the ambiguity of their EU position between the two elections (Figure 4). In other words, mainstream parties not only became notably more supportive of the EU in 2017, they were also more willing to become explicitly and openly so. If parties have blurred their EU positions in the past because they believe doing so is electorally advantageous (Adam et al., 2017), adopting a deblurring strategy suggests that parties view clear positions on the EU to be electorally profitable. 


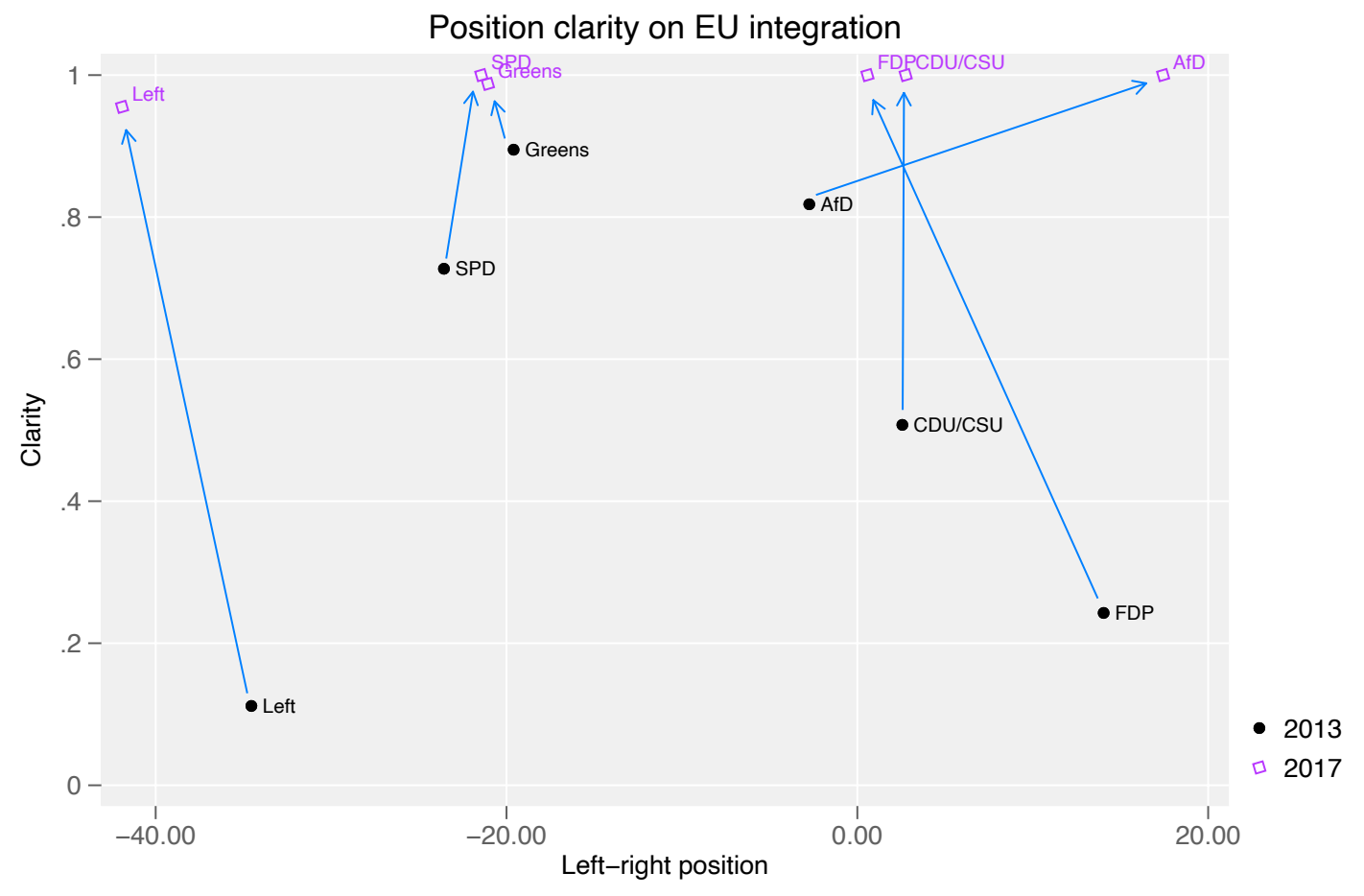

Figure 4: (De)blurring of EU positions

\section{Electoral motivations}

The behaviour of political parties in Germany in the face of a eurosceptic challenger goes against spatial expectations and the contagious euroscepticism thesis (Meijers, 2017). Theoretical understandings of how parties respond to political entrepreneurs suggest that parties will seek to stop the haemorrhaging of voters to these parties by altering their own policy positions to reflect a spatial stance that is similar to the challenger (Downs, 1957), even in multiparty and multidimensional settings (AbouChadi, 2016; Abou-Chadi and Krause, 2018; Adams and Somer-Topcu, 2009; Bale et al., 2010; Van Spanje, 2010). What, then, explains the increase in pro-european stances of parties observed in the 2017 German federal elections in the face of an increasing viable threat from the eurosceptic AfD? 
Rohrschneider and Whitefield (2017) argue that mainstream parties resist against spatial motivations to adapt their positions on EU integration in response to the electoral threat of eurosceptic challengers because of reputational constraints (Rohrschneider and Whitefield 2017: 84). In other words, parties positions are constrained by the "stickiness" of their past ideological commitments (Hooghe and Marks, 2018). This echoes the expectations of the issue yield model (DeSio and Weber, 2014) which views the responsiveness of party positions to challengers as risky. Unlike Downs, this model of strategic party competition, including in multiparty systems (DeSio et al., 2018), does not posit that party stances change, which would provoke a number of electoral $\operatorname{costs}^{\mathrm{vii}}$ on parties, but rather expects parties who are comparatively disadvantaged by challengers who "own" a particularly issue to focus on politicising issues that are cohesively supported by their own voters, as well as the wider electorate (DeSio et al., 2016; DeSio and Weber, 2014) viii. The main governing parties in Germany who have maintained a consistent pro-European stance since the foundation of European community are unable to abandon their europhile reputations without electoral consequences. Parties, after all, present themselves to the electorate as an ideologically coherent package and a general brand for electoral consumption (Lupu, 2014). This packaging creates positional associations that, when reversed, undermine the perceived credibility of the brand which leads voters to cast their ballot elsewhere. As a result, whilst parties do adapt and alter both their positions on policy debates and adopt new issues, the malleability of their ideological catalogues tends to remain with 
the boundaries of the presented ideological space their brand seeks to take up (Adams and Somer-Topcu, 2009; Hooghe and Marks, 2018). This may explain a lack of spatial adaptation towards euroscepticism but preoccupations over damaging the party's proEU brand do not explain why parties actually increased their pro-European messaging or the clarity of the same.

I argue that partisan efforts to strengthen their europhile positions can be understood by vote-seeking motivations. Although Germany saw a collapse in popular support for the $\mathrm{EU}$ in the wake of the financial crisis, the emergence of the AfD and the increasing politicisation of the EU coincides with a shift back toward pro-EU sentiment in 2017 amongst the majority of voters. In the 2017 federal elections, political parties on the mainstream were presented with polarly distinct spatial motivators to adapt their policy positions.

On the one hand, they were presented with a growing and electorally successful eurosceptic party that was pulling voters from their traditional sources of vote revenue, particularly in the case of the CDU and the SPD (Lees, 2018). On the other hand, successive eurosceptic gains by the AfD correlate with a return towards pro-european sentiment amongst the majority. It may be that EU politicisation is sparked by political entrepreneurs (De Vries and Hobolt, 2020; Hooghe and Marks, 2018) like the AfD who seek to monopolise latent eurosceptic opinion in the electorate, but it appears that the silent majority in Germany retains a positive view of the European project 
and parties, therefore, are doubling down on their pro-European positions in the face of the eurosceptic alternative. This is consistent with Franzmann and colleagues, who argue that, in 2017, (pro) EU positions provided mainstream parties with the highest issue yield - indicating that both their supporters and the wider electorate were strongly supportive of the EU (Franzmann, Giebler, and Poguntke 2020: 627). Strategically using this issue in response to the conflict mobilisation techniques of the challenger (DeSio and Lachat, 2020) would be a vote-maximising response.

If vote-seeking motivations explain the increase in europhilia witnessed by the mainstream parties, one would expect to see a shift in the demand-side of European attitudes amongst these parties' supporters. Using data provided by the seventh and ninth wave of the European Social Survey (respectively fielded after the 2013 and 2017 elections), I present evidence that this is indeed the case. Empirically, I estimate an OLS regression models regressing individual-level support for the EU on a categorical variable capturing partisan vote choice, alongside a vector of control variables, in independent models for 2013 and 2017.

The models controls for basic demographics - sex and age - as well as several wellestablished determinants EU support: rural/urban location (De Vries, 2018), education (Hakhverdian et al., 2013), income (Gabel, 1998), religiosity (Nelsen et al., 2011), attitudes towards immigration (Hooghe and Marks, 2005; McLaren, 2002), and 
satisfaction with the democracy and the economy (De Vries, 2018; Sánchez-Cuenca, 2000).

Sex is measured dichotomously $(1=$ male $)$ and age is measured in years. Education is indicated via a continuous variable that indicates the total number of years in education. Income is measured by individuals' placement on a 10-point indicator capturing the income percentile to which they identify with. Religiosity of individuals captures those self-identify on a continuous scale from "Not at all religious" (0) to "Very religious" (10). Immigration is controlled for via the inclusion of a 10-point measure that indicates those who think that immigration is bad (0) or good (10) thing. Satisfaction with the economy is also controlled for and records individuals' retrospective evaluations of the performance of the economy with higher (lower) values indicating more (less) satisfaction with the economy, and satisfaction with democracy is measured in a similar fashion.

Table 2 reports the output from the main regression analysis. Model 1 and Model 2 estimate the different levels of support for the EU in 2013 amongst the voters of the six main parties (baseline: CDU) with and without controls respectively. Model 3 and Model 4 replicate these specifications for 2017. Post-stratification weights are applied. 
Table 2: Modelling German voters' support for the EU

\begin{tabular}{|c|c|c|c|c|}
\hline & \multicolumn{2}{|c|}{2013} & \multicolumn{2}{|c|}{2017} \\
\hline & (Model 1) & (Model 2) & (Model 3) & (Model 4) \\
\hline \multicolumn{5}{|l|}{ Party (baseline: $C D U$ ) } \\
\hline \multirow[t]{2}{*}{ SPD } & 0.13 & $0.30^{* *}$ & -0.11 & 0.01 \\
\hline & $(0.15)$ & $(0.14)$ & $(0.18)$ & $(0.17)$ \\
\hline \multirow[t]{2}{*}{ die Grünen } & -0.36 & 0.26 & 0.02 & -0.04 \\
\hline & $(0.23)$ & $(0.23)$ & $(0.26)$ & $(0.27)$ \\
\hline \multirow[t]{2}{*}{ die Linke } & $1.37 * * *$ & $1.05^{* * *}$ & $0.83^{* * *}$ & $0.47^{* * *}$ \\
\hline & $(0.19)$ & $(0.19)$ & $(0.17)$ & $(0.18)$ \\
\hline \multirow[t]{2}{*}{ FDP } & 0.44 & 0.28 & $-0.54^{* *}$ & $-0.49^{* *}$ \\
\hline & $(0.29)$ & $(0.28)$ & $(0.24)$ & $(0.23)$ \\
\hline \multirow[t]{2}{*}{$\mathrm{AfD}$} & $-1.95^{* * *}$ & $-0.79^{* *}$ & $-3.19^{* * *}$ & $-1.72^{* * *}$ \\
\hline & $(0.31)$ & $(0.32)$ & $(0.27)$ & $(0.30)$ \\
\hline \multirow[t]{2}{*}{ Sex (male) } & & -0.07 & & -0.20 \\
\hline & & $(0.12)$ & & $(0.13)$ \\
\hline \multirow[t]{2}{*}{ Age } & & -0.00 & & $-0.01^{* *}$ \\
\hline & & $(0.00)$ & & $(0.00)$ \\
\hline \multirow[t]{2}{*}{ Urban } & & -0.02 & & 0.02 \\
\hline & & $(0.12)$ & & $(0.15)$ \\
\hline \multirow[t]{2}{*}{ Income } & & -0.02 & & -0.04 \\
\hline & & $(0.02)$ & & $(0.02)$ \\
\hline \multirow[t]{2}{*}{ Education } & & $0.05^{* *}$ & & $0.04^{*}$ \\
\hline & & $(0.02)$ & & $(0.02)$ \\
\hline \multirow[t]{2}{*}{ Political interest } & & -0.05 & & $-0.24^{* * *}$ \\
\hline & & $(0.09)$ & & $(0.09)$ \\
\hline \multirow[t]{2}{*}{ Religiosity } & & $0.04^{*}$ & & 0.01 \\
\hline & & $(0.02)$ & & $(0.02)$ \\
\hline \multirow[t]{2}{*}{ Support for immigration } & & $0.39^{* * *}$ & & $0.26^{* * *}$ \\
\hline & & $(0.03)$ & & $(0.04)$ \\
\hline \multirow[t]{2}{*}{ Satisfaction with the economy } & & $0.08^{* *}$ & & 0.07 \\
\hline & & $(0.04)$ & & $(0.04)$ \\
\hline \multirow[t]{2}{*}{ Satisfaction with democracy } & & $0.22^{* * *}$ & & $0.20^{* * *}$ \\
\hline & & $(0.03)$ & & $(0.04)$ \\
\hline \multirow[t]{2}{*}{ Constant } & $5.52^{* * *}$ & 0.69 & $6.59^{* * *}$ & $3.97 * * *$ \\
\hline & $(0.10)$ & $(0.53)$ & $(0.11)$ & $(0.59)$ \\
\hline Observations & 2,005 & 1,853 & 1,571 & 1,437 \\
\hline R-squared & 0.06 & 0.26 & 0.12 & 0.23 \\
\hline
\end{tabular}

Robust standard errors (two-tailed) in parentheses $* * * \mathrm{p}<0.01,{ }^{* *} \mathrm{p}<0.05,{ }^{*} \mathrm{p}<0.1$ 
I am primarily interested in the relationship between partisanship and support for the EU, although one may note that, amongst the control variables, there is a significant and positive relationship between support for immigration and support for the EU, confirming the correlated nature of these "twin" issues (Brinkmann and Panreck, 2019; Turnbull-Dugarte, 2020a).

I turn to the predictive margins for the interpretation of the results. The plots presented in Figure 5 report the predicted levels of support for EU among the different parties' supporters in 2013 (Model 2) and 2017 (Model 4), controlling for the specified covariates. Amongst the mainstream parties, there was no asymmetric level of support for the EU in 2013 with the exception of die Grünen whose constituents were significantly $(\mathrm{p}<0.01)$ more pro-EU than those of the other parties. As expected, the voters of the AfD were significantly and substantially more eurosceptic than voters from all of the mainstream parties. 


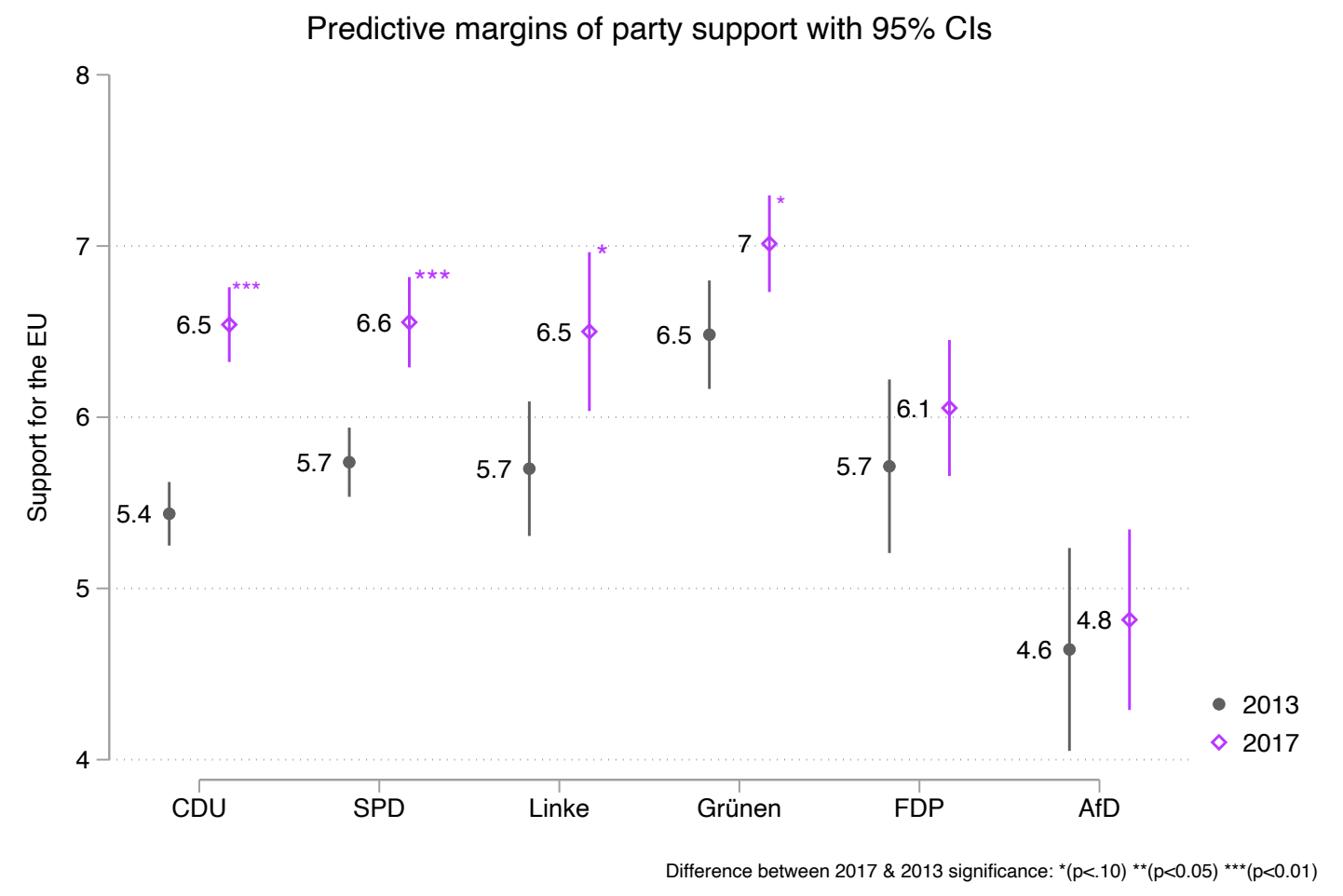

Figure 5: Partisan voter change in support for the EU

Apart from the AfD and the FDP, all other party supporters became significantly more europhile in 2017. In the case of the Grand Coalition parties, their voters observed an increase of close to one full unit on the eleven-point $(0-10)$ scale $(\mathrm{p}<0.01)$, moving away from a centrist position and converging towards the europhile space previously monopolised by die Grünen. The voters of die Grünen, already the most pro-European in the electorate, became more europhile, increasing their mean position from 6.5 to 7 $(\mathrm{p}<0.10)$.

The euroscepticism of AfD's voters remains unchanged in 2017. This is noteworthy for two reasons. Firstly, that the eurosceptic tendencies of the party's voters have remained static is in itself interesting as whilst the party has gained a substantial 
increase in electoral support between 2013 and 2017 (increasing its vote share from 1.9 percent to 11.5 in the first vote and from 4.7 to 12.6 in the second vote) the fact that the eurosceptic nature of its voters has not changed as a result suggests that the euroscepticism we observe in the party's voters is likely its core "base rate" despite the fact that the party itself increased its euroscepticism between these two elections (recall Figure 2).

Second, it is striking that the increased spread of preferences on the issue amongst party supporters between 2013 and 2017 is being driven by mainstream party voters becoming more europhile not because of the drives towards euroscepticism. In other words, moves on the EU dimension have taken place amongst the voting constituents of the mainstream parties rather than the AfD. The implication being that the arrival of a threat to the pro-European consensus has served as something of a wake-up call for the complacent and permissive eurocentrists who have now become europhiles.

One might make the argument that the alteration in the support for the EU for each of the parties' voters might be a reflection of wider shifts towards more liberal/leftist attitudes. Testing for this possibility, however, suggests that this is not the case. For example, Figure 6 below repeats the model estimations presented in Figures 5 above using two alternative dependent variables: i) general ideological placement on the left vs right socio-economic axis, and ii) support for immigration (full regression output reported in the online appendix). Both of these variables are constructed on a eleven- 
point $(0-10)$ scale: in the case of the former, higher values indicate a more right-leaning position, and in the case of immigration, higher values indicate greater levels of support.

\section{Predictive margins of party support with $95 \% \mathrm{Cls}$}

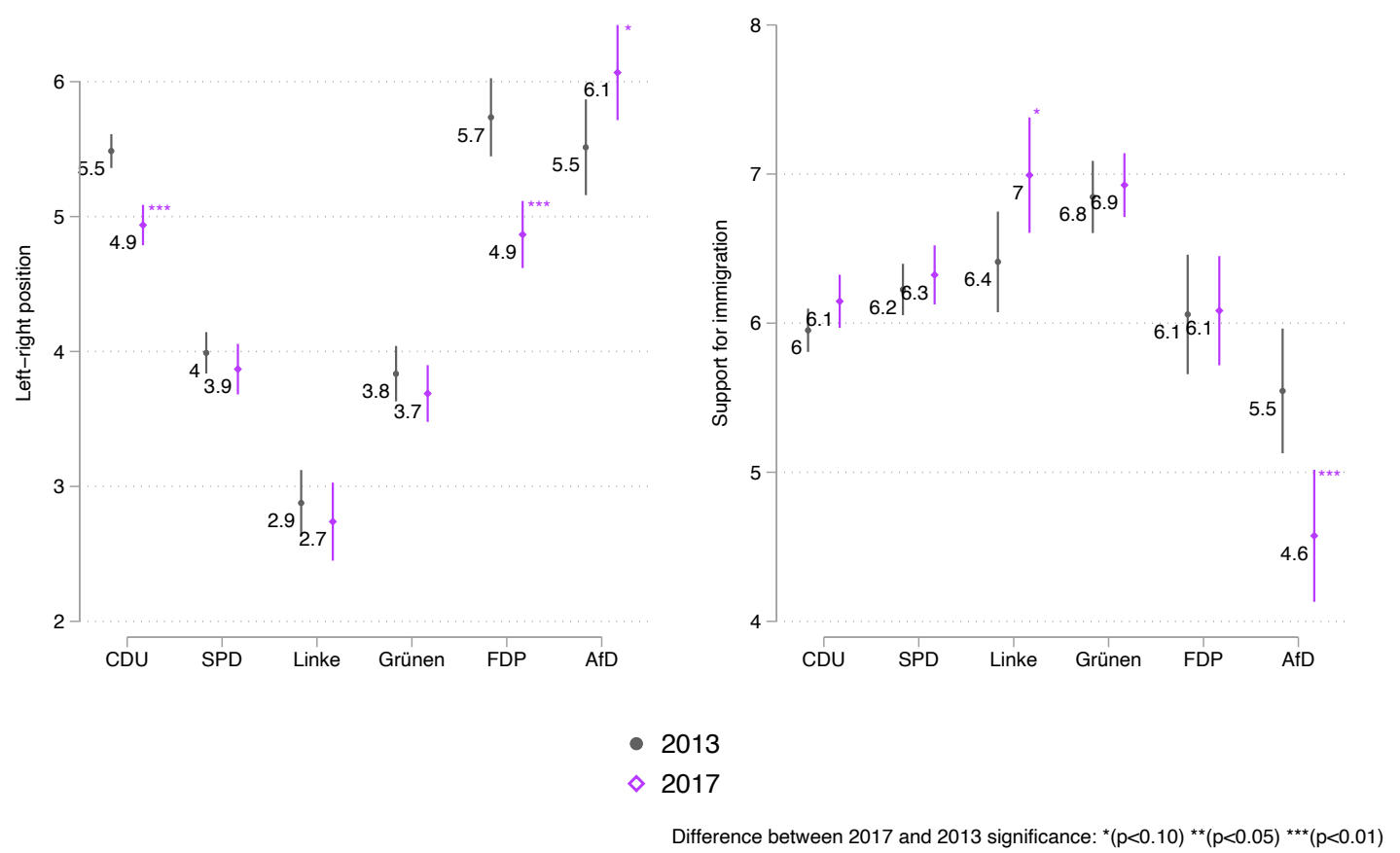

\section{Figure 6: Changing partisan voter attitudes across different dimensions}

As demonstrated, there is no evidence that shifts towards a more europhile position are symptomatic of a wider expansion of more liberal policy positions amongst the electorates of the mainstream parties. On the general left-right axis (left-hand panel), only the voters of the CDU and FDP observe any shift in their position that is significant, with the voters of both parties shifting towards the left and adopting a more centrist position. This may be because those with more right-leaning positions previously supportive of these parties have changed their voting preferences in favour of the AfD. Note that whilst in 2013, the voters of the AfD held a left-right position 
that was statistically indistinguishable from that of the FDP and the CDU, with the move to the centre of these two parties and the shift rightwards of AfD voters, the voters of the eurosceptic party became significantly more right-leaning than their peers in 2017 (Arzheimer and Berning, 2019).

Far less movement in voter preferences is observed in the case of immigration. Only the voters of the AfD appear to have significantly altered their position between 2013 and 2017 on this issue, becoming less supportive of immigration in the most recent election which is consistent with existing findings and coincides with the increasing saliency of immigration concerns of the party leaders (Arzheimer and Berning, 2019; Hansen and Olsen, 2019). The voters of die Grünen appear to have become more supportive of immigration, but the significance of the change is less robust.

Importantly, this test shows no systematic shifts in voters' preferences on these additional issues. I maintain that the emergence of a credible eurosceptic threat can explain the shift in party positions towards the EU. The rise of the AfD signals to voters that an extremist and eurosceptic alternative challenges their latent support for the supranational polity so voters become more prone to express a more favourable position towards the EU. Mainstream parties are responding simultaneously to this by also focusing on the high yield that pro-EU positions can provide them with (De Sio and Weber 2014; Franzmann, Giebler, and Poguntke 2020). 


\section{Conclusions}

The results show that a rising eurosceptic challenger is not enough to upset the proEuropean consensus of the established parties. This is likely attributable to the shifts towards europhilia exhibited by the voters of these parties between these two elections. The longitudinal trends in popular attitudes towards Europe demonstrate that support began trending upwards from 2016 long before the federal election campaign began or before the political parties would have redacted their electoral manifestos. This suggests the direction of causality, but it cannot isolate it. Faced with an electorally successful partisan threat, mainstream parties, in contrast to the spatial model yet expected from the issue yield model (DeSio et al., 2018; DeSio and Weber, 2014), have preferred to follow the preferences of their voters and, have actually doubled down on their europhile stance.

Whilst I have shown that there was both a sizeable and significant increase in the proEuropean stances of political parties in 2017 compared to previous elections, this study is not without its limitations. I am unable to isolate the causal mechanism that engendered this change and other events may have played a role. Although possible such an effect is not probable. At least, it appears, that a cross-national effect can be ruled out given that if one were to have occurred, there would be a rise in proEuropean stances by parties across member states which is not the case with parties still appearing to turn towards more eurosceptic positions (Rohrschneider and 
Whitefield 2017: 84). It is more likely the case that experiencing the materialisation of a legitimate eurosceptic threat drives parties to respond adversarially to defend positions that they hope will mobilise and attract the pro-European masses against the eurosceptic minority. Partisan europhilia does not solely follow public opinion. Despite the fall in popular EU support at the height of the Eurozone crisis, parties' EU positions remained largely unchanged and only showed a dramatic shift in 2017 with AfD increasing in electoral support.

Empirically showing that the rise of a eurosceptic challenger does not engender eurosceptic shift among existing parties is important for a number of reasons. Scholars have warned that the rise of the AfD signals a turning point in Germany's relationship with the EU (Arzheimer, 2015; Lees, 2018) given that having an eurosceptic party with enough electoral support to become the main leader of the opposition (as is the German case) threatens the pro-European consensus. The rise of the $\mathrm{AfD}$ has done little to create systemic euroscepticism. Of course, Germany is just one country, yet it is worth noting that in Europe's biggest and most powerful member state, we do not observe empirical evidence to support the contagious euroscepticism effect.

Theoretically, the paper contributes to the understanding of the role of eurosceptic challenger success by arguing that the establishment of a legitimate threat to the continued membership of the EU can act as a rallying call to those sympathetic to the European project. The rise of a threat to EU membership drives voters to be more 
supportive of EU integration and parties react along the same europhile direction of travel. The German case study involving the rise of the AfD detailed in this analysis is just one example, but other cases may observe similar effects. The UK's decision to leave the EU, and the subsequent negative economic and political effects for the country, may equally spark a desire among those in support of the EU that the treat of disintegration is one that should not be ignored.

In Germany, the emergence of a new radical-right eurosceptic party in the form of the AfD threatened to bring about the end of the pro-EU consensus within both the Germany party system as well as within the wider electorate. The 2017 federal election in Germany, however, shows that the mainstream is willing to fight back. Political parties from across the left-right divide have responded to the initial electoral success of the AfD by altering their positions on European integration to become more explicitly pro-European. Whilst it is clear that the aggressively eurosceptic campaign strategy and policy position of the AfD has left a noteworthy mark on the policies of the German mainstream in relation to European integration, the effect has been to reinvigorate a new hope for europhiles by mobilising the mainstream to come out in defence of Europe. 
i This assumption is not without empirical critique. O'Grady and Abou-Chadi (2019) argue that claims of party responsiveness are often not substantiated, showing that party positions, across multiple dimensions, do not in fact mirror those supported by the public.

ii Green/alternative/liberal-traditional/authoritarian/nationalist (Hooghe et al., 2002). Also referred to as the transnational cleavage (Hooghe and Marks, 2018).

iii Alternative measures of EU support such as De Vries' (2018) regime and policy differential paint a similar picture. With both increasing substantively following the AfD's success in the EP election (see Figures A6-A7).

ivI use the term "crisis" here in line with uses elsewhere although it is worth acknowledging that referring to the arrival of refugees seeking asylum in Europe as a "crisis" is politically charged.

v Whilst die Linke has taken, at times, a critical stance of the EU (Hertner and Sloam, 2012; Lees, 2002), it has never taken a position of outright opposition to the EU or advocated for Germany's exit from the monetary union.

vi The reliance on manifesto data is not uncontested (see, Benoit, Laver, and Mikhaylov 2009). One alternative is to rely on expert surveys (Polk et al., 2017) but these are problematic given that they don't give a real-time measure of a position during a concrete election and are often prone to the stickiness of reputational associations which makes their use for temporal change problematic (Budge, 2000). Replications of the analysis presented using CHES data shows littleto-no change in the positions of the CDU/CSU and the SPD between 2014 and 2017.

${ }^{\text {vii }}$ In their assessment of the electoral support of social democratic parties across forty-two elections, Abou-Chadi and Wagner (2020) show that adopting less liberal positions on the GALTAN dimensions, including specifically on EU integration, can be detrimental to social democratic parties' electoral fortunes.

viii De Sio and Weber (2020) demonstrate this this is electorally advantageous and show that focusing on policies with high issue yields actually increases a party's vote share. 


\section{Acknowledgments}

I am indebted to Christel Koop, Rubén Ruiz-Rufino, Sara B. Hobolt and Ignacio Sánchez-Cuenca for their rigorous critique and assessment of earlier iterations of this paper. I also acknowledge the helpful recommendations of the two anonymous peer reviewers.

\section{Disclosure Statement}

No potential conflict of interest was reported by the author.

\section{Funding}

This work received support from the UK's Economic and Social Research

Council under grant number ES/J500057/1.

\section{ORCID}

Stuart J. Turnbull-Dugarte https://orcid.org/0000-0002-9330-3945

\section{References}

Abou-Chadi T (2016) Niche Party Success and Mainstream Party Policy Shifts - How

Green and Radical Right Parties Differ in Their Impact. British Journal of

Political Science 46(2): 417-436.

Abou-Chadi T and Krause W (2018) The Causal Effect of Radical Right Success on Mainstream Parties' Policy Positions: A Regression Discontinuity Approach. 
British Journal of Political Science 50(3): 829-847.

Abou-Chadi T and Wagner M (2020) Electoral fortunes of social democratic parties: do second dimension positions matter? Journal of European Public Policy 27(2): 246272.

Adam S, Antl-Wittenberg EM, Eugster B, et al. (2017) Strategies of pro-European parties in the face of a Eurosceptic challenge. European Union Politics 18(2): 260282. DOI: $10.1177 / 1465116516661248$.

Adams J and Somer-Topcu Z (2009) Policy Adjustment by Parties in Response to Rival Parties' Policy Shifts: Spatial Theory and the Dynamics of Party Competition in Twenty-Five Post-War Democracies. British Journal of Political Science 39(4): 825-846.

Adams J, Ezrow L and Somer-Topcu Z (2014) Do voters respond to party manifestos or to a wider information environment? An analysis of mass-elite linkages on European integration. American Journal of Political Science 58(4): 967-978.

Arnold C, Sapir E V. and DeVries CE (2012) Parties' Positions on European Integration: Issue Congruence, Ideology or Context? West European Politics 35(6): 1341-1362. DOI: 10.1080/01402382.2012.713749.

Arzheimer K (2015) The AfD: Finally a Successful Right-Wing Populist Eurosceptic Party for Germany? West European Politics 38(3): 535-556. DOI: 10.1080/01402382.2015.1004230.

Arzheimer K and Berning CC (2019) How the Alternative for Germany (AfD) and their voters veered to the radical right, 2013-2017. Electoral Studies 60. Elsevier. 
Bakker R, Jolly S and Polk J (2012) Complexity in the European party space:

Exploring dimensionality with experts. European Union Politics 13(2): 219-245.

Bale T (2003) Cinderella and her ugly sisters: The mainstream and extreme right in

Europe's bipolarising party systems. West European Politics 26(3): 67-90. DOI:

10.1080/01402380312331280598.

Bale T, Green-Pedersen C, Krouwel A, et al. (2010) If You Can't Beat Them, Join

Them? Explaining Social Democratic Responses to the Challenge from the

Populist Radical Right in Western Europe. Political Studies 58(3): 410-426. DOI:

10.1111/j.1467-9248.2009.00783.x.

Benoit K, Laver M and Mikhaylov S (2009) Treating words as data with error:

Uncertainty in text statements of policy positions. American Journal of Political

Science 53(2): 495-513. DOI: 10.1111/j.1540-5907.2009.00383.x.

Berbuir N, Lewandowsky M and Siri J (2015) The AfD and its sympathisers: Finally a right-wing populist movement in Germany? German Politics 24(2): 157-178.

Berk RA, Western B and Weiss RE (1995) Statistical Inference for Apparent

Populations. Sociological Methodology 25: 421-458. DOI: 10.2307/271073.

Bräuninger T and Giger N (2018) Strategic Ambiguity of Party Positions in MultiParty Competition. Political Science Research and Methods 6(3): 527-548. DOI: 10.1017/psrm.2016.18.

Brinkmann HU and Panreck C-I (2019) Migration und Rechtspopulismus - zwei Seiten einer Medaille? Eine gängige These der Rechtspopulismusforschung auf dem Prüfstand. In: Brinkmann HU and Panreck C-I (eds) Rechtspopulismus in 
Einwanderungsgesellschaften. Die Politische Auseinandersetzung Um Migration

Und Integration. Ebook: Springer, pp. 1-21.

Budge I (2000) Expert judgements of party policy positions: Uses and limitations in political research. European Journal of Political Research 37(1): 103-113. DOI: 10.1111/1475-6765.00506.

Budge I (2001) Validating the Manifesto Research Group Approach: theoretical assumptions and empirical confirmations. In: Laver M (ed.) Estimating the Policy Position of Political Actors. Colchester: ECPR Press, pp. 50-65.

Budge I, Ezrow L and McDonald MD (2010) Ideology, Party Factionalism and Policy Change: An integrated dynamic theory. British Journal of Political Science 40(4): 781-804. DOI: 10.1017/s0007123409990184.

Carvalho J (2013) Impact of Extreme Right Parties on Immigration Policy: Comparing Britain, France and Italy. London: Routledge. DOI: 10.4324/9781315885162.

Conti N (2018) National political elites, the EU, and the populist challenge. Politics 38(3): 361-377. DOI: 10.1177/0263395718777363.

De Vries C (2018) Euroscepticism and the Future of European Integration. Euroscepticism and the Future of European Integration. Oxford: Oxford University Press.

De Vries CE and Hobolt SB (2020) Political Entrepeneurs. The Rise of Challenger Parties in Europe. Princeton, New Jersey: Princeton University Press.

DeSio L and Lachat R (2020) Making sense of party strategy innovation: challenge to ideology and conflict-mobilisation as dimensions of party competition. West 
European Politics 43(3): 688-719. DOI: 10.1080/01402382.2019.1655967.

DeSio L and Weber T (2014) Issue yield: A model of party strategy in multidimensional space. American Political Science Review 108(4): 870-885. DOI: 10.1017/S0003055414000379.

DeSio L and Weber T (2020) Issue yield, campaign communication, and electoral performance: a six-country comparative analysis. West European Politics 43(3): 720-745. DOI: 10.1080/01402382.2019.1655968.

DeSio L, Franklin MN and Weber T (2016) The risks and opportunities of Europe: How issue yield explains (non-)reactions to the financial crisis. Electoral Studies 44. Elsevier Ltd: 483-491. DOI: 10.1016/j.electstud.2016.06.006.

DeSio L, DeAngelis A and Emanuele V (2018) Issue Yield and Party Strategy in Multiparty Competition. Comparative Political Studies 51(9): 1208-1238. DOI: 10.1177/0010414017730082.

Devine D (2019) Perceived government autonomy, economic evaluations, and political support during the Eurozone crisis. West European Politics EarlyView. DOI: 10.1080/01402382.2019.1675130.

Downs A (1957) An Economic Theory of Democracy. New York: Harper \& Row. Franzmann ST, Giebler H and Poguntke T (2020) It's no longer the economy, stupid! Issue yield at the 2017 German federal election. West European Politics 43(3): $610-638$.

Gabel M (1998) Public support for European integration: An empirical test of five theories. Journal of Politics 60(2): 333-354. DOI: 10.2307/2647912. 
Giebler H, Meyer TM and Wagner M (2019) The changing meaning of left and right: supply- and demand-side effects on the perception of party positions. Journal of Elections, Public Opinion and Parties EarlyView. DOI:

10.1080/17457289.2019.1609001.

Hakhverdian A, Van Elsas E, Van der Brug W, et al. (2013) Euroscepticism and education: A longitudinal study of 12 EU member states, 1973-2010. European Union Politics 14(4): 522-541.

Han KJ (2015) The Impact of Radical Right-Wing Parties on the Positions of Mainstream Parties Regarding Multiculturalism. West European Politics 38(3): $557-576$.

Hansen MA and Olsen J (2019) Flesh of the Same Flesh: A Study of Voters for the Alternative for Germany (AfD) in the 2017 Federal Election. German Politics 28(1): 1-19.

Hertner I and Sloam J (2012) The Europeanisation of the German Party System. In: European and Party Politics: How the EU Affects Domestic Actors, Parties and Systems. Colchester: ECPR Press, pp. 45-54.

Hooghe L and Marks G (2005) Calculation, community and cues: Public opinion on European integration. European Union Politics 6(4): 419-443.

Hooghe L and Marks G (2018) Cleavage theory meets Europe's crises: Lipset, Rokkan, and the transnational cleavage. Journal of European Public Policy 25(1): 109-135.

Hooghe L, Marks G and Wilson CJ (2002) Does left/right structure party positions on European integration? Comparative Political Studies 35(8): 965-989. DOI: 
10.1017/CBO9780511492013.008.

Hutter S and Grande E (2014) Politicizing Europe in the national electoral arena: A comparative analysis of five west European Countries, 1970-2010. Journal of Common Market Studies 52(5): 1002-1018.

Lees C (2002) 'Dark matter': Institutional constraints and the failure of party-based euroscepticism in Germany. Political Studies 50(2): 244-267.

Lees C (2018) The 'Alternative for Germany': The rise of right-wing populism at the heart of Europe. Politics 38(3): 295-310.

Lowe W, Benoit K, Slava M, et al. (2011) Scaling policy preferences from coded political texts. Legislative Studies Quarterly 36(1): 123-155.

Lupu N (2014) Brand dilution and the breakdown of political parties in Latin America. World Politics 66(4): 561-602.

Mader M and Schoen H (2019) The European refugee crisis, party competition, and voters' responses in Germany. West European Politics 42(1): 67-90.

Mair P (2000) The limited impact of Europe on national party systems. West European Politics 23(4): 27-51.

Marx P and Naumann E (2018) Do right-wing parties foster welfare chauvinistic attitudes? A longitudinal study of the 2015 'refugee crisis' in Germany. Electoral Studies 52: 111-116.

McLaren LM (2002) Public support for the European union: Cost/benefit analysis or perceived cultural threat? Journal of Politics 64(2): 551-566.

Meguid BM (2005) Competition between unequals: The role of mainstream party 
strategy in niche party success. American Political Science Review 99(3): 347-359.

Meijers MJ (2017) Contagious Euroscepticism: The impact of Eurosceptic support on mainstream party positions on European integration. Party Politics 23(4): 413423.

Nelsen BF, Guth JL and Highsmith B (2011) Does religion still matter? Religion and public attitudes toward integration in Europe. Politics and Religion 4(1): 1-26. DOI: $10.1017 /$ S1755048310000507.

O'Grady T and Abou-Chadi T (2019) Not so responsive after all: European parties do not respond to public opinion shifts across multiple issue dimensions. Research $\mathscr{E}$ Politics 6(4): 1-7.

Polk J, Rovny J, Bakker R, et al. (2017) Explaining the salience of anti-elitism and reducing political corruption for political parties in Europe with the 2014 Chapel Hill Expert Survey data. Research and Politics 4(1): 1-9. DOI: $10.1177 / 2053168016686915$.

Rohrschneider R and Whitefield S (2017) Party positions about european integration in Germany: An electoral quandary? German Politics 26(1): 83-103. DOI: 10.1080/09644008.2016.1189532.

Rovny J (2012) Who emphasizes and who blurs? Party strategies in multidimensional competition. European Union Politics 13(2): 269-292. DOI: $10.1177 / 1465116511435822$.

Sánchez-Cuenca I (2000) The Political Basis of Support for European Integration. European Union Politics 1(2): 147-171. 
Schmitt-Beck R (2017) The 'alternative für deutschland in the electorate': Between single-issue and right-wing populist party. German Politics 26(1): 124-148. DOI: 10.1080/09644008.2016.1184650.

Schneider CJ and Slantchev BL (2018) The Domestic Politics of International Cooperation: Germany and the European Debt Crisis. International Organization 72(1): 1-31. DOI: 10.1017/s0020818317000406.

Schulte-Cloos J (2018) Do European Parliament elections foster challenger parties' success on the national level? European Union Politics 19(3): 408-426.

Schumacher G and van Kersbergen K (2014) Do mainstream parties adapt to the welfare chauvinism of populist parties? Party Politics 22(3): 300-312. DOI: $10.1177 / 1354068814549345$.

Schumacher G, De Vries CE and Vis B (2013) Why do parties change position? party organization and environmental incentives. Journal of Politics 75(2): 464-477. DOI: $10.1017 /$ S0022381613000145.

Somer-Topcu Z (2009) Timely decisions: The effects of past national elections on party policy change. Journal of Politics 71(1): 238-248. DOI: 10.1017/S0022381608090154.

Spoon JJ and Williams C (2017) It takes two: how Eurosceptic public opinion and party divisions influence party positions. West European Politics 40(4): 741-762. DOI: $10.1080 / 01402382.2016 .1277876$.

Steenbergen MR, Edwards EE and De Vries CE (2007) Who's cueing whom?: MassElite linkages and the future of European integration. European Union Politics 
8(1): 13-35. DOI: 10.1177/1465116507073284.

Turnbull-Dugarte SJ (2020a) Multidimensional issue preferences of the European lavender vote. Journal of European Public Policy EarlyView. DOI:

10.1080/13501763.2020.1804987.

Turnbull-Dugarte SJ (2020b) The impact of EU intervention on political parties' politicisation of Europe following the financial crisis. West European Politics 43(4): 894-918.

Van Spanje J (2010) Contagious parties: Anti-immigration parties and their impact on other parties' immigration stances in contemporary western europe. Party Politics 16(5): 563-586. DOI: 10.1177/1354068809346002.

Walgrave S and Nuytemans M (2009) Friction and party manifesto change in 25 countries, 1945-98. American Journal of Political Science 53(1): 190-206. DOI: 10.1111/j.1540-5907.2008.00365.x.

Williams C and Ishiyama J (2018) Responding to the left: The effect of far-left parties on mainstream party Euroskepticism. Journal of Elections, Public Opinion and Parties 28(4): 443-466. DOI: 10.1080/17457289.2018.1434783.

Williams C and Spoon JJ (2015) Differentiated party response: The effect of Euroskeptic public opinion on party positions. European Union Politics 16(2): 176-193. DOI: 10.1177/1465116514564702. 


\section{Appendix}

Table A 1 Summary statistics (i)

\begin{tabular}{lccccc}
\hline \multicolumn{1}{c}{ Variable } & N & Mean & Standard deviation & Min & Max \\
\hline Year & 28 & & & 2002 & 2017 \\
EU saliency & 28 & -3.44 & 0.56 & -4.48 & -1.81 \\
EU position & 28 & 1.68 & 2.17 & -4.78 & 5.62 \\
Clarity & 28 & 0.66 & 0.32 & 0 & 1 \\
\hline
\end{tabular}

Table A 2 Summary statistics (ii)

\begin{tabular}{cc}
\hline Party & Number of manifestos \\
\hline SPD & 5 \\
CDU/CSU & 5 \\
FDP & 5 \\
Die Grünen & 5 \\
Left & 5 \\
AfD & 2 \\
\hline
\end{tabular}

EU position is defined as follows: $\frac{P=\log \left(S_{\text {pos }}+0.5\right)-\log \left(S_{n e g}+0.5\right)}{S_{\text {pos }}+S_{\text {neg }}+1}$

EU saliency can be defined as follows:

$E S=\log \frac{S_{\text {pos }}+S_{\text {neg }}+1}{N}$

Where $S_{\text {pos }}$ and $S_{\text {neg }}$ indicate the number of quasi sentences in the manifesto dedicated to positive and negative stances on EU integration respectively. Where $P$ indicates a party's overall EU position and $E S$ indicates the saliency of EU integration for each party in a given election. Operationalisation based on Lowe et al. (2011).

Clarity (C) is defined as the absolute value of the following (Turnbull-Dugarte 2020) and indicates a clarity score running from 0 (completely blurred position with equal number of quasi-sentences in favour of / opposed to policy) to 1 (unambiguously in favor of / opposed to policy):

$C=\frac{S_{p o s}-S_{n e g}}{S_{\text {pos }}+S_{\text {neq }}}$ 
Table A 3 Alternative hypothesis (i): Testing partisan blurring of EU positions

\begin{tabular}{lcc}
\hline & \multicolumn{2}{c}{ Clarity } \\
& 2017 vs 2013 & 2017 vs 2002-2013 \\
\hline & $0.51^{* * *}$ & $0.44^{* * *}$ \\
& $(0.12)$ & $(0.07)$ \\
Constant & $0.48^{* * *}$ & $0.55^{* * *}$ \\
& $(0.12)$ & $(0.07)$ \\
Observations & 11 & 26 \\
R-squared & 0.62 & 0.30 \\
\hline Robust standard errors (two-tailed) in parentheses \\
$* * * \mathrm{p}<0.01,{ }^{* *} \mathrm{p}<0.05,{ }^{*} \mathrm{p}<0.1$
\end{tabular}

Table A 4 Alternative hypothesis (ii): testing changes in overall ideological position

\begin{tabular}{lcc}
\hline & \multicolumn{2}{c}{ Left-right ideological position } \\
& 2017 vs 2013 & 2017 vs 2002-2013 \\
\hline \multirow{3}{*}{2017} & -3.92 & -10.32 \\
& $(10.96)$ & $(8.58)$ \\
Constant & -12.29 & -5.89 \\
& $(7.35)$ & $(3.88)$ \\
& & \\
Observations & 11 & 26 \\
R-squared & 0.01 & 0.05 \\
\hline
\end{tabular}

Robust standard errors (two-tailed) in parentheses

$$
* * * \mathrm{p}<0.01, * * \mathrm{p}<0.05, * \mathrm{p}<0.1
$$


Table A 5: Demand-side summary statistics

\begin{tabular}{lcccccc}
\hline Variable & Observations & Mean & SD & Min & Median & Max \\
\hline Party Vote & 3290 & 2.48 & 1.56 & 1.00 & 2.00 & 6.00 \\
Sex & 3290 & 0.54 & 0.50 & 0.00 & 1.00 & 1.00 \\
Age & 3290 & 53.4 & 16.84 & 18.00 & 54.00 & 93.00 \\
Income & 3290 & 6.32 & 2.71 & 1.00 & 7.00 & 10.00 \\
Education & 3290 & 14.79 & 3.35 & 2.00 & 14.00 & 40.00 \\
Urban/Rural & 3290 & 0.31 & 0.46 & 0.00 & 0.00 & 1.00 \\
Political interest & 3290 & 1.97 & 0.74 & 1.00 & 2.00 & 4.00 \\
Religious & 3290 & 4.08 & 2.98 & 0.00 & 4.00 & 10.00 \\
EU support & 3290 & 5.97 & 2.74 & 0.00 & 6.00 & 10.00 \\
Left-right position & 3254 & 4.44 & 1.94 & 0.00 & 5.00 & 10.00 \\
Immigration support & 3290 & 6.18 & 2.22 & 0.00 & 6.00 & 10.00 \\
Year & 3290 & & & 2013 & & 2017 \\
\hline
\end{tabular}

Difference (t-test) between 2017 and pre-2017 elections by party
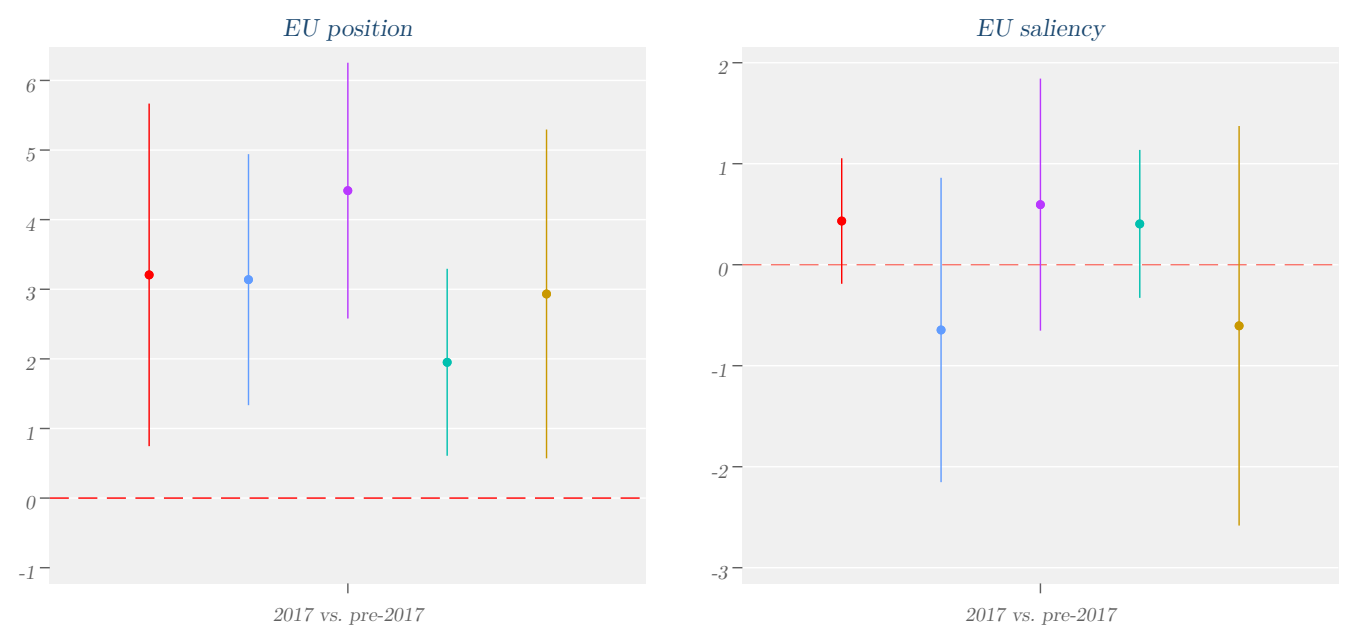

$$
\begin{array}{ll}
\text { - } & S P D \\
\text { - } & C D U / C S U \\
\text { - } & F D P \\
\text { - } & \text { Die Grünen } \\
\text { - } & \text { Die Linke }
\end{array}
$$

Figure A 1: Party asymmetry in EU politicisation 


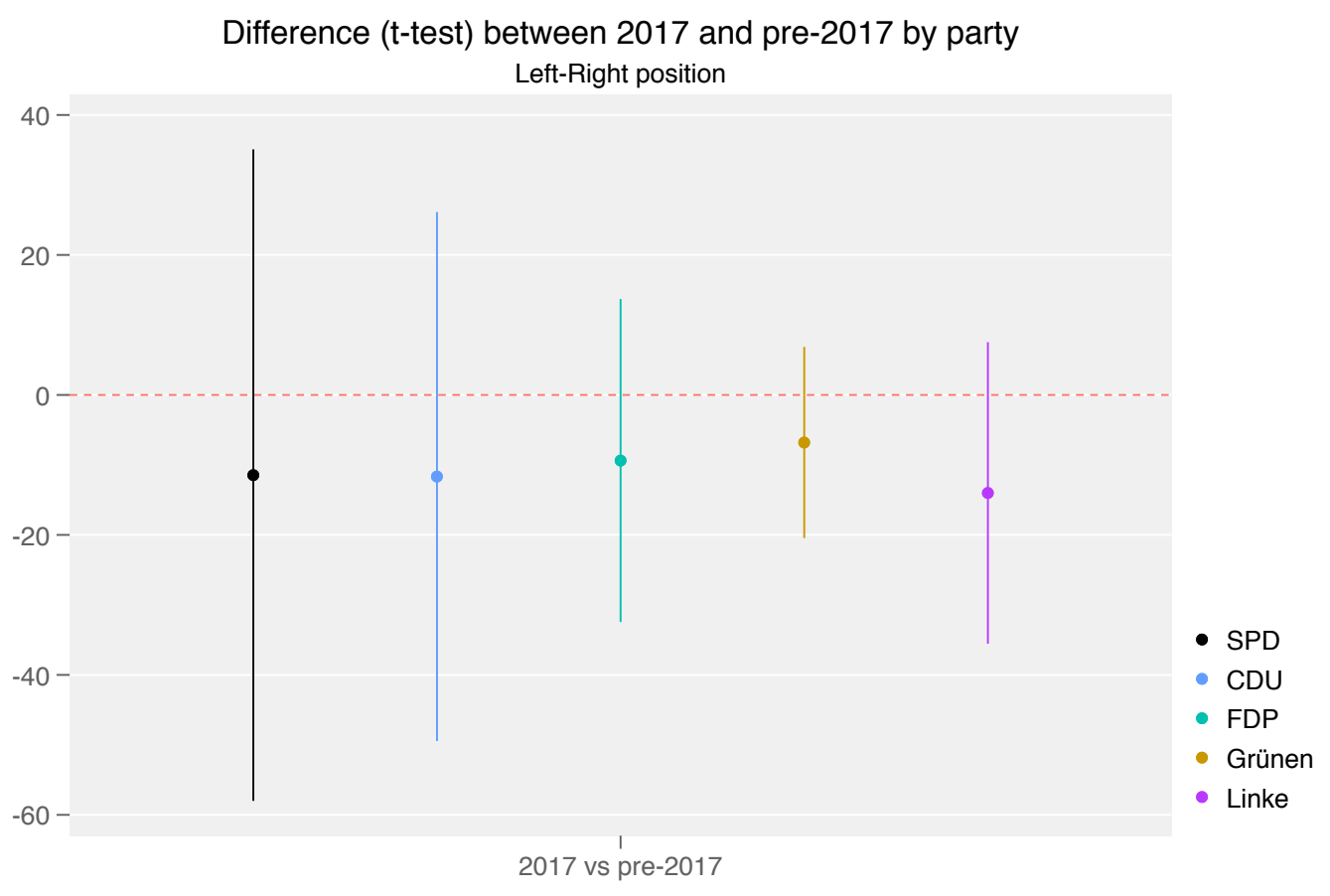

Figure A 2: Left-right changes by party 


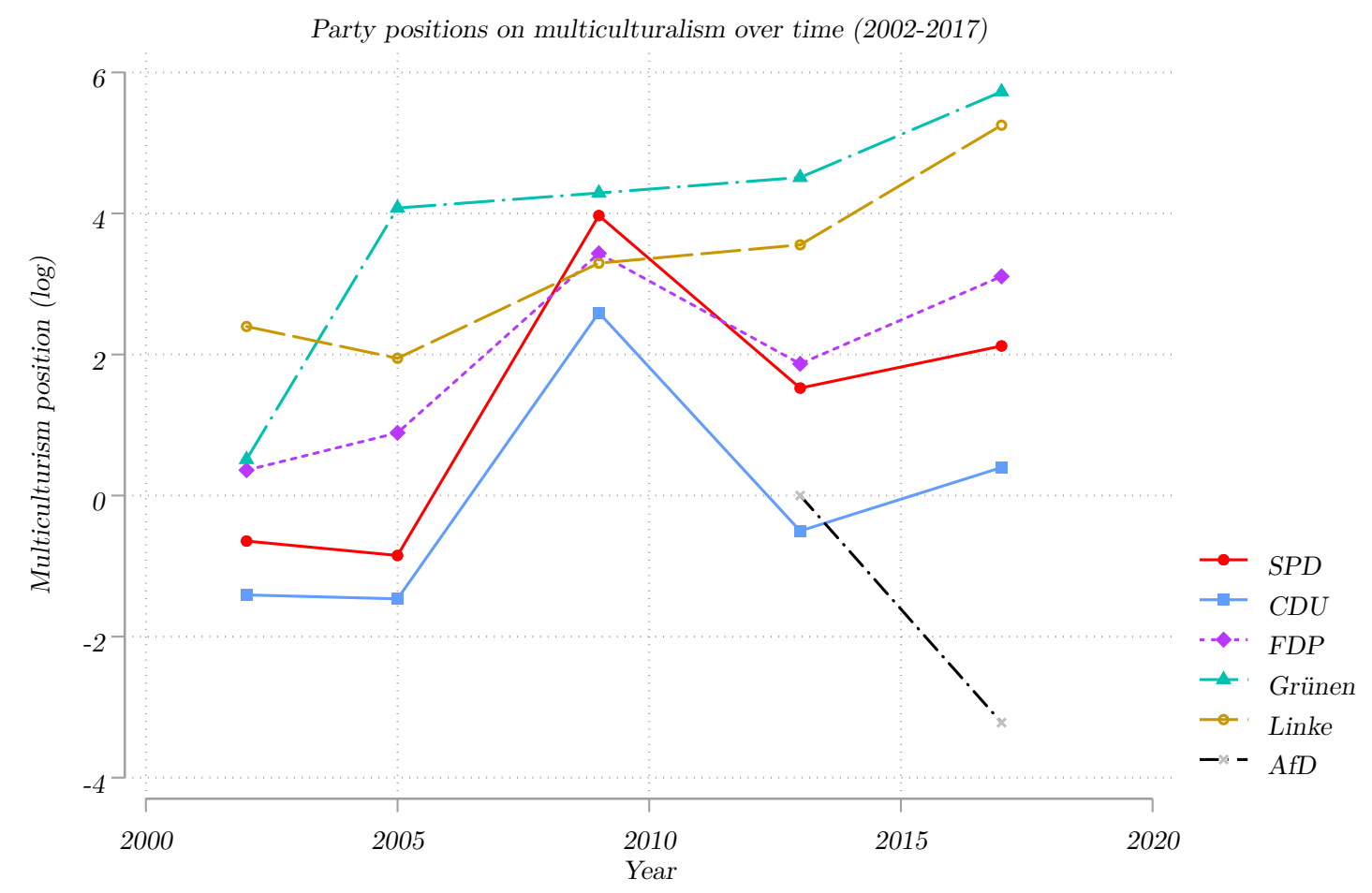

Figure A 3: Changes in multiculturalism (immigration)

EU politicisation over time (2002-2017)
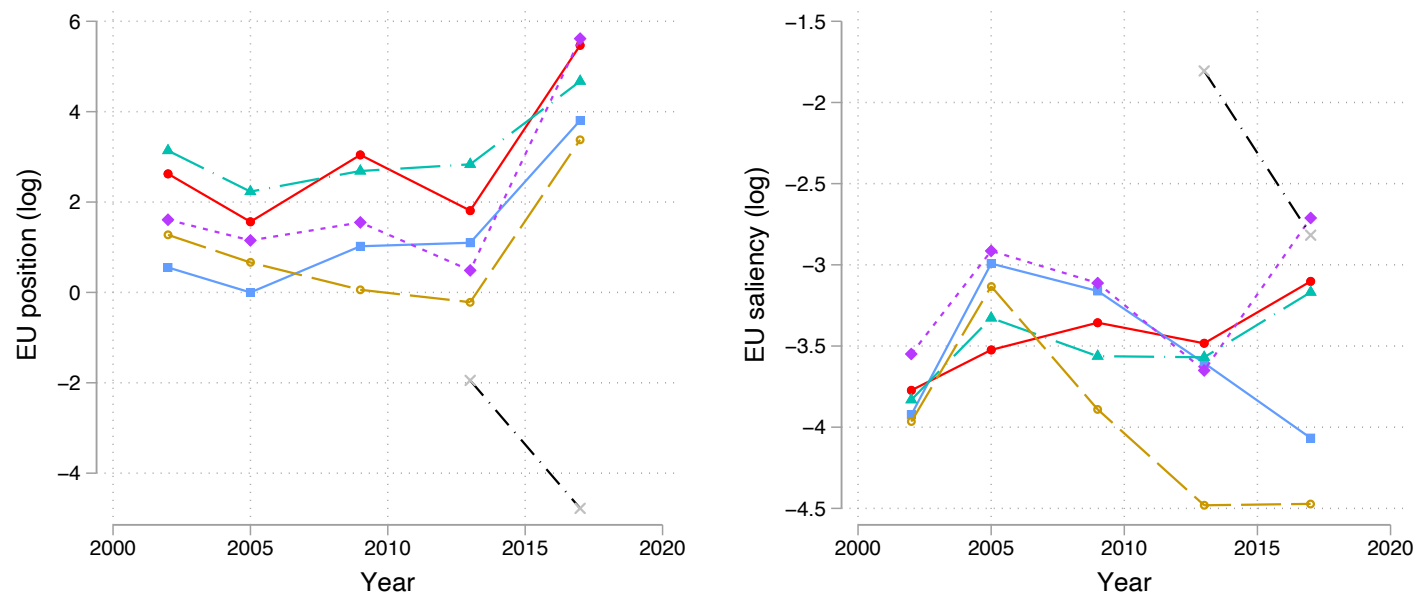

$$
\begin{array}{ll}
\rightarrow & \text { SPD } \\
\rightarrow- & \text { CDU } \\
-\rightarrow & \text { FDP } \\
\longrightarrow & \text { die Grünen } \\
\longrightarrow & \text { die Linke } \\
\longrightarrow- & \text { AfD }
\end{array}
$$

Figure A 4: 2002-2017 trends 


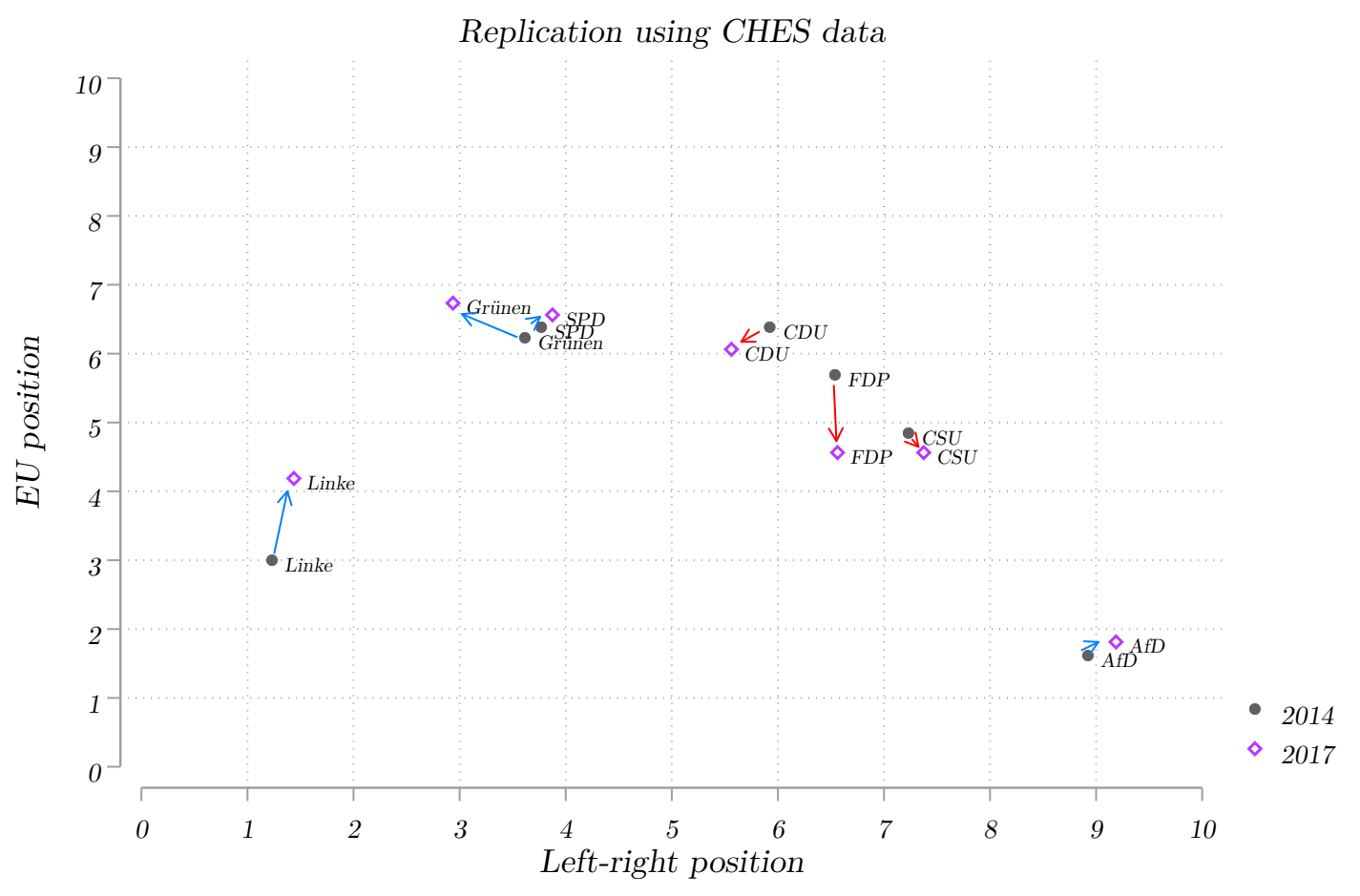

Figure A 5: Figure 2 using CHES data 
Table A 6: Alternative demand-side tests

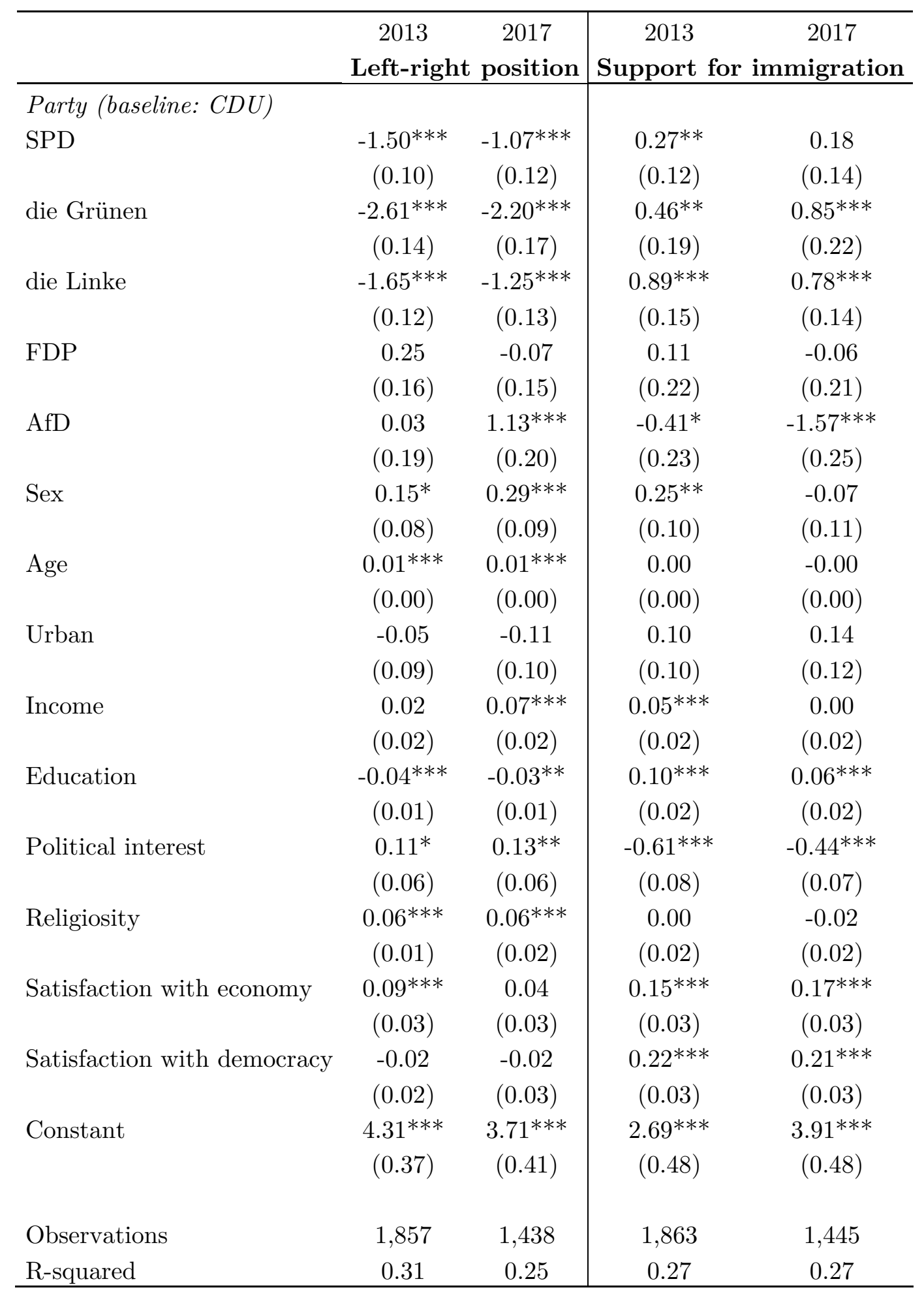

Robust standard errors (two-tailed) in parentheses

$$
{ }^{* * *} \mathrm{p}<0.01,{ }^{* *} \mathrm{p}<0.05,{ }^{*} \mathrm{p}<0.1
$$




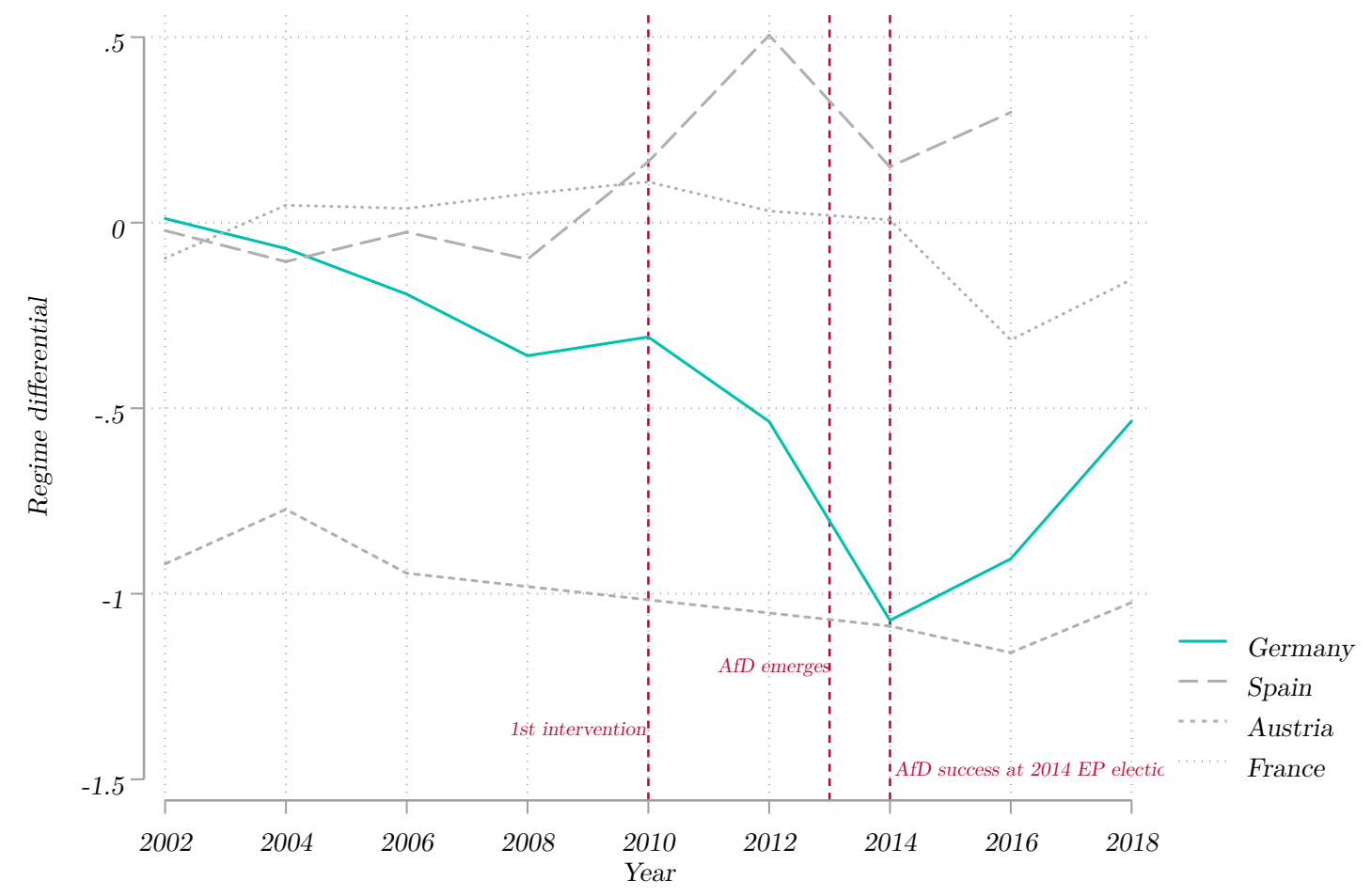

Figure A 6: DeVries (2020) Regime differential

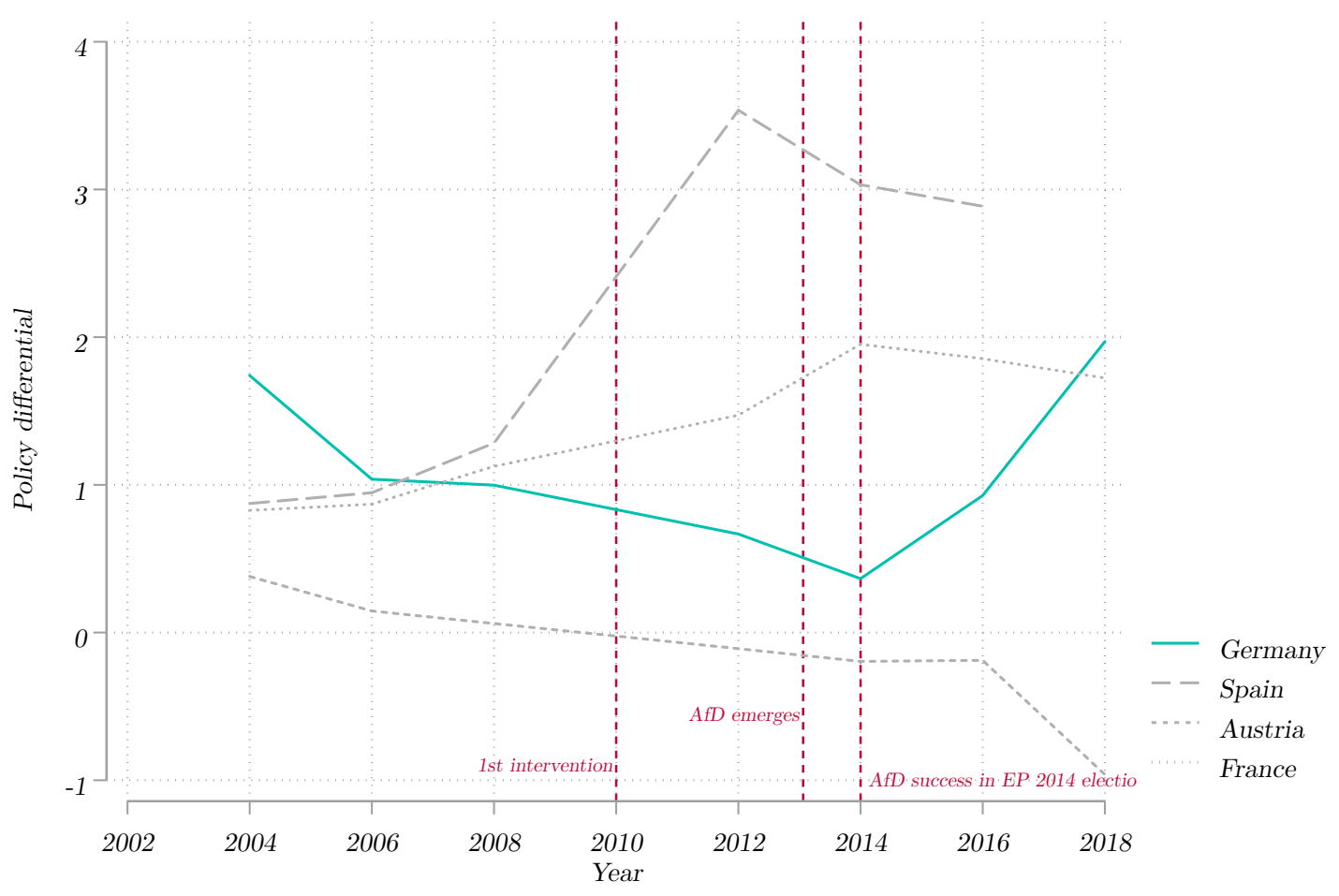

Figure A 7: DeVries (2020) policy differential 